\title{
VEGETATION OF HAWAIIAN LAVA FLOWS
}

\author{
VAUGHAN MacCaUgheY \\ (WITH TWENTY-TWO FIGURES)
}

\section{Introduction}

This paper is a survey of the more important types of vegetation which occur on the lava fields of the Hawaiian Archipelago and their ecological relations. It has particular reference to the spermatophytes, as our taxonomic knowledge of the native land algae, lichens, bryophytes, and pteridophytes is still in a somewhat fragmentary and unsettled condition. The scope of the paper is further restricted by including only the arid or xerophytic districts where the lava flows are relatively barren. Under humid climate the flows rapidly disintegrate into rich volcanic soil and support a luxuriant rain forest. This paper is concerned with the ecology of the xerophytic regions, as these have largely been neglected in the literature of Hawaiian botany.

There is a widespread association of ideas which couples tropical with humid conditions, due no doubt to the many semipopular accounts of the "tropical jungle" and to the types of vegetation usually exhibited in the northern conservatories. It requires a distinct readjustment of perspective to realize that many tropical regions possess large areas of extreme aridity. The Hawaiian Archipelago, situated just within the tropics in the center of the North Pacific Ocean, admirably illustrates this condition. Most of the popular and semitechnical accounts of the islands have emphasized the beautiful humid woodlands and have either ignored or given scant attention to the vast rocky waste lands of barren lava flow and cinder field.

It has been the writer's privilege, during a residence of 8 years in the islands, to have made many expeditions into these arid regions and to have ascended all of the high mountains of the group. This paper is an outgrowth of these trips, some of which have occupied many weeks. In order to make clear the ecological 
background of this lava flow vegetation, it is necessary to sketch briefly the salient features of the Hawaiian volcanic mountains. Detailed accounts may be found in such standard works as those of Hitchcock, Brigham, Dana, and Dutton.

It will be noted that the present paper deals largely with the ecological conditions under which the lava flow vegetation exists. A comprehensive annotated list of the lava flow plants is now appearing in the Journal of The Linnaean Society.

\section{Classification of islands}

From the standpoint of area occupied by lava flows, cinder fields, and other waste lands resultant from volcanic activity, the islands may be divided into two groups: (I) the lesser islands (Niihau, Kauai, Oahu, Molokai, Lanai, Kahoolawe); and (2) the greater islands (Maui and Hawaii, see figs. I, 2). The lesser islands are, as a whole, of much greater antiquity than Maui and Hawaii. The erosive agencies have been at work for a much longer time, hence the lava flows have been almost wholly turned into soil. There are some traceable flows still existent on some of the lesser islands, Kauai, Oahu (figs. 3, 4, 5), Molokai, and Lanai, for example, but these are relatively non-consequential as compared with the great stretches of lava covered country on Hawaii and Maui. The lava waste lands, above the timber line, on Mauna Loa alone, for example, occupy a greater area than the entire island of Oahu, Kauai, or Molokai. Thus a discussion of the vegetation of the Hawaiian lava flows is naturally restricted chiefly to a consideration of the islands of Maui and Hawaii, the largest and youngest end of the long archipelago. No account is given in this paper of the tiny islands which are strewn over a long axis for 1800 miles to the westward of the larger, inhabited islands. Some of these are volcanic rocks, but the majority are tiny reefs and shoals. ${ }^{\mathrm{I}}$ Their total area is only 6 sq. miles. All are highly xerophytic.

IsLAND OF HawaII.-Hawaii, the largest island of the archipelago ( 4015 sq. miles), is about the size of the state of Connecticut, with a maximum diameter of 93 miles (fig. 2). Its area is greater

${ }^{x}$ MacCaughey, V., The little end of Hawaii. Jour. Geography 15:23-26. I9I6. 
than that of all the other islands combined. It is composed of 5 volcanic masses. The northernmost, the Kohala Mountains, is of extreme antiquity, deeply eroded, and probably as old as Kauai.

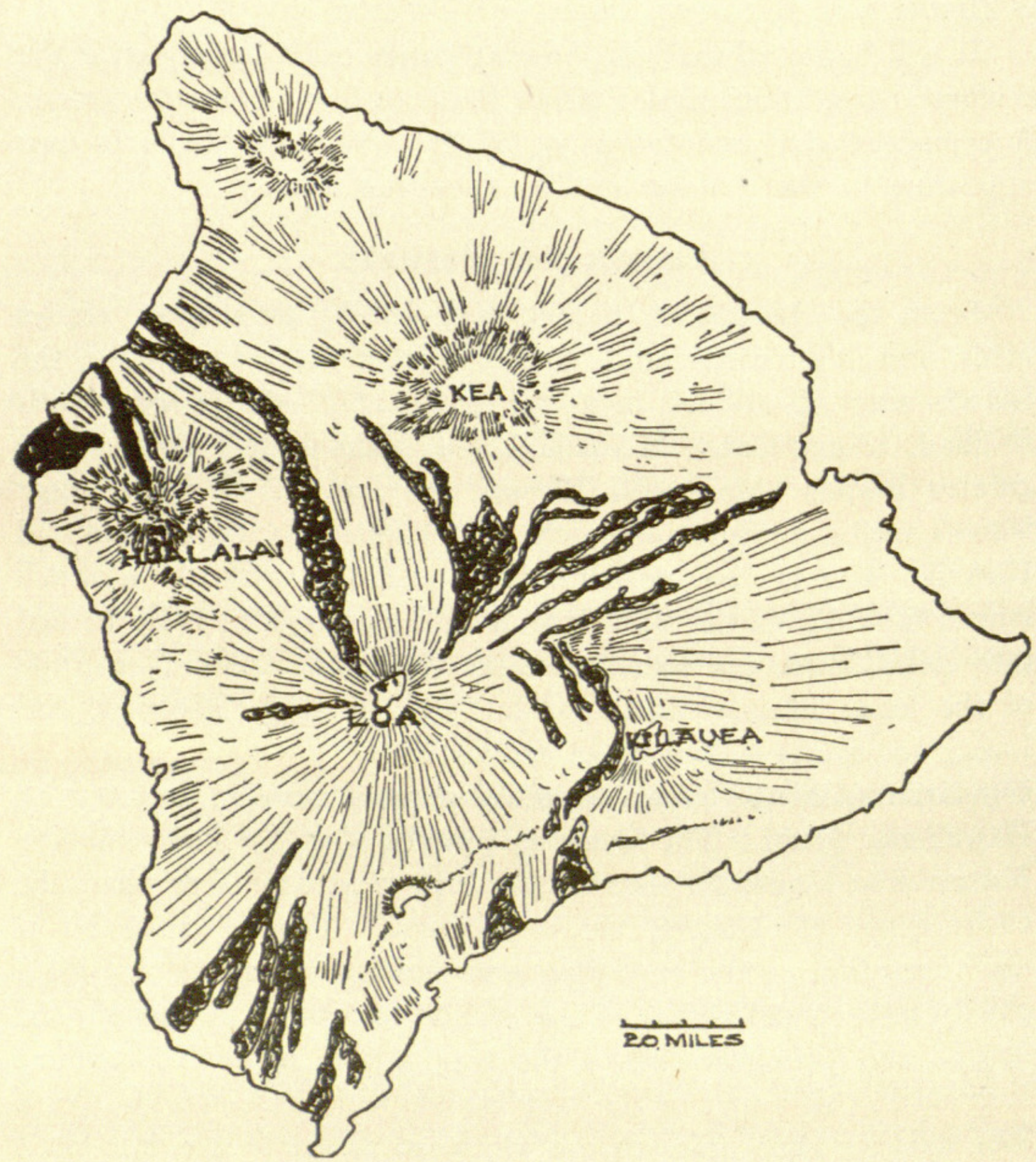
flows.

Fig. I.-Island of Hawaii, showing high mountains and principal recent lava

Mauna Kea and Hualalai, next toward the south, have become "extinct" within comparatively recent times; a lava flow issued from Hualalai in r8or. Mauna Kea has given no manifestations of activity within historic times. It is the highest point within the North Pacific Ocean. 
The two southern mountains, Mauna Loa (figs. 6, 7) and Kilauea, are active volcanoes. Their summit craters have exhibited spectacular activity at intermittent periods throughout historic time, and vast lava flows have emanated from their flanks. A large flow issued from the southern slopes of Mauna Loa in May I9r6. Loa dominates the island of Hawaii and is the greatest volcanic mountain in the world. The elevations of 5 volcanic

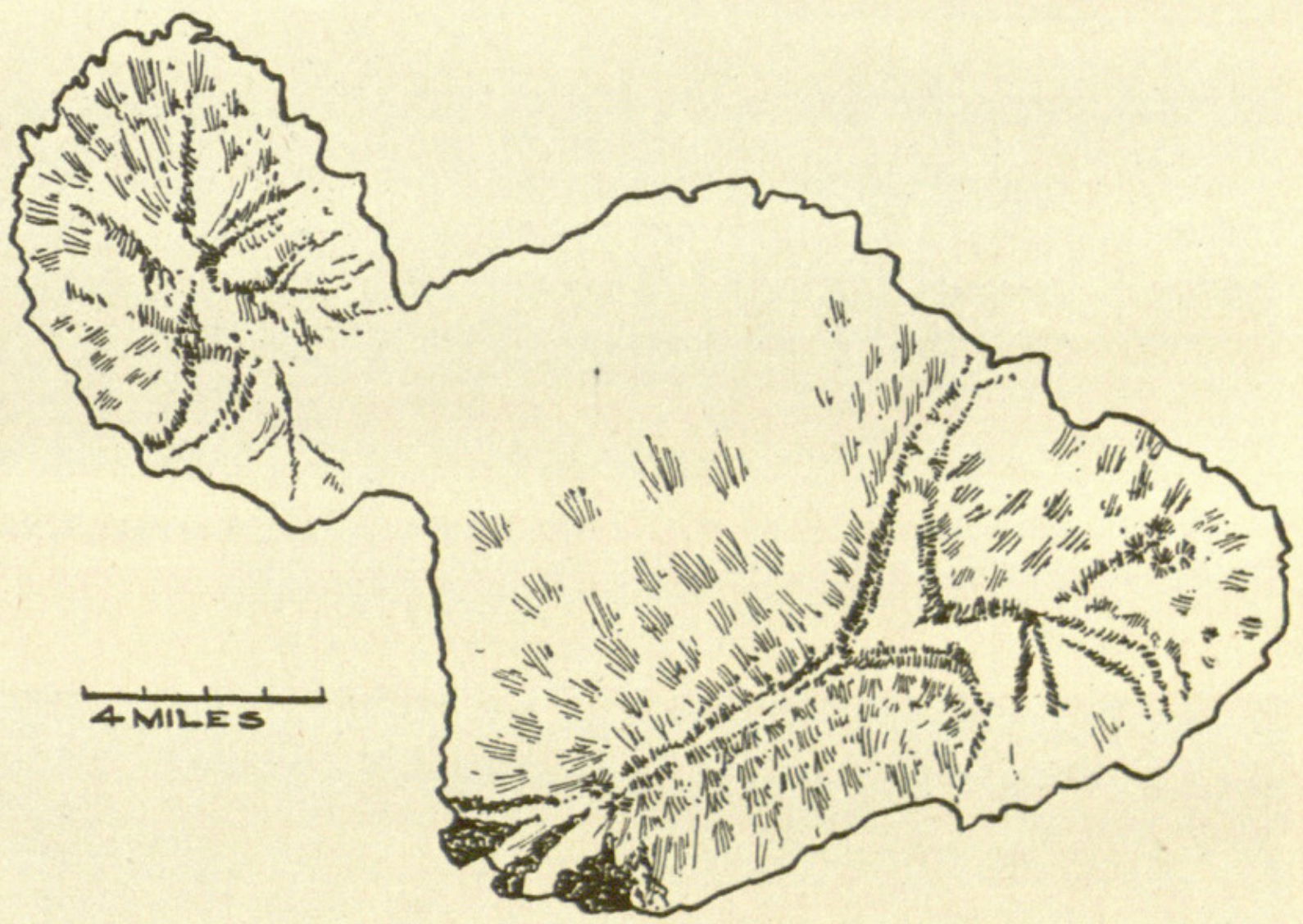

FIG. 2.- Island of Maui: Mount Haleakala comprises entire eastern lobe of island; lava flow country at summit, in caldera, and on southeastern slopes of mountain; regions are largely xerophytic, with exposed lava fields, fields of cinder and ash, cinder cones, and pit craters.

masses of Hawaii are as follows: Kohala Mountains, $5489 \mathrm{ft}$.; Mauna Ket, I3,825 ft.; Hualalai, $8269 \mathrm{ft}$; Mauna Loa, I3,675 ft.; Kilauea, $4000 \mathrm{ft}$.

Haleakala ON MAUI.-Haleakala (fig. 8) is the great mountain that forms the entire eastern portion of the island of Maui. The summit is $10,032 \mathrm{ft}$. above sea level. It contains a great volcanic caldera, one of the largest in the world, 7.5 miles long by 2.5 miles wide and over $2000 \mathrm{ft}$. deep. This mountain, often called East Maui, is very much younger than the deeply eroded western mass. 


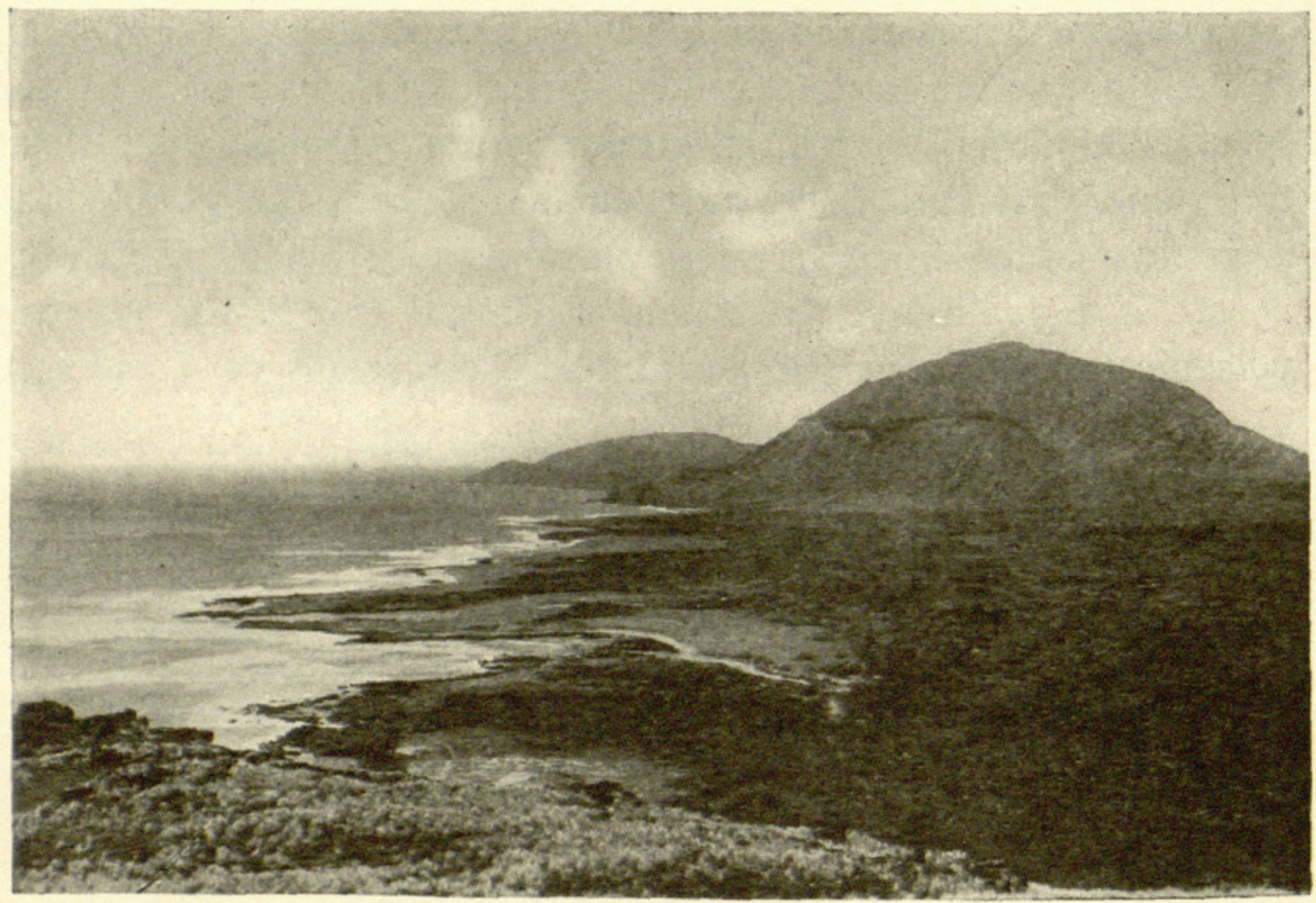

FIG. 3.-Tufa cones and xerophytic lava fields, Oahu; open crater to right, Koko Crater; hill beyond to left, Koko Head.

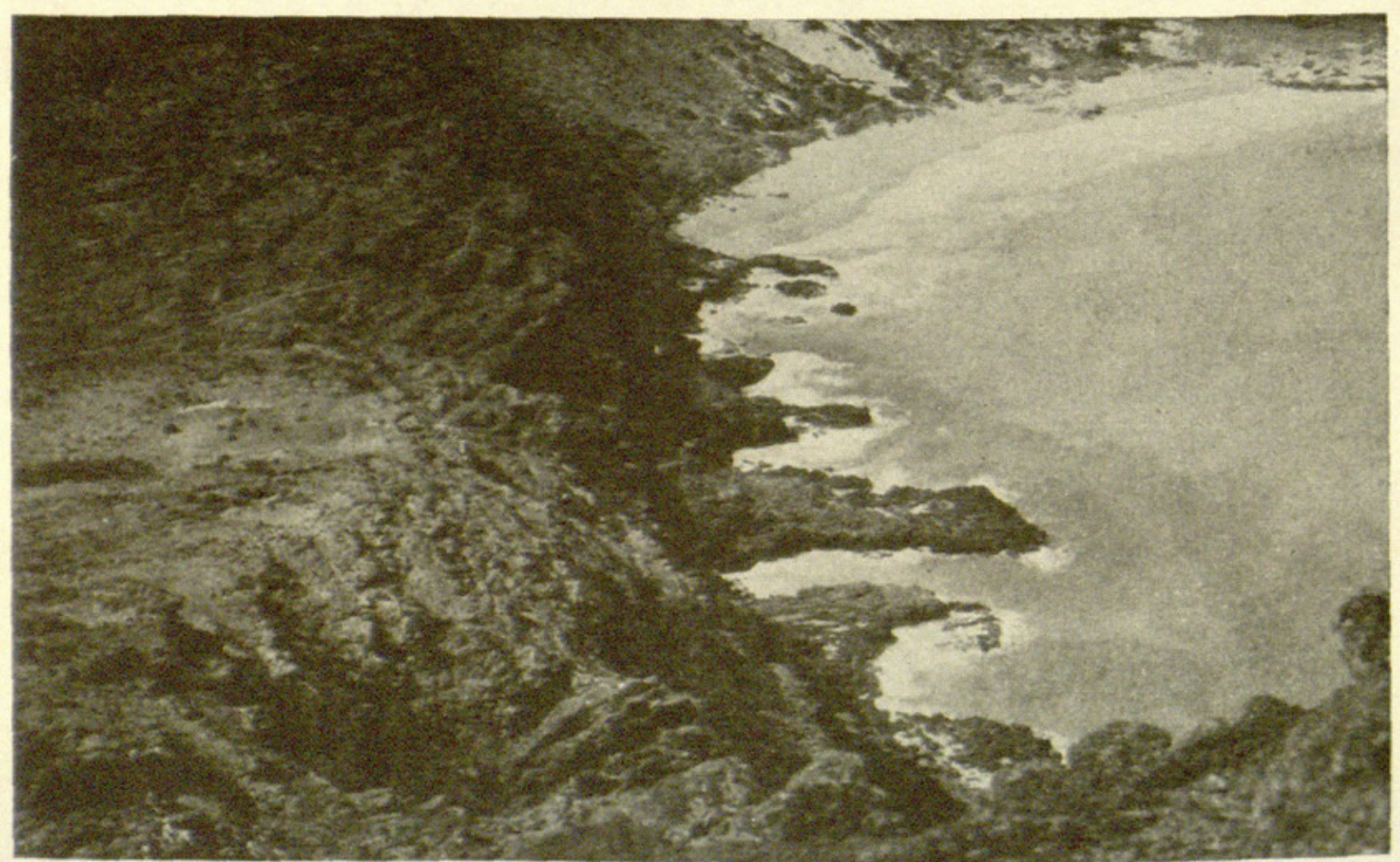

Fig. 4.-Arid headland, Maka-pu'u, Oahu, illustrating ancient lava sheets exposed by extensive erosion; note stratification of lava flows and erosion of flows at sea level. 
Maui is a volcanic doublet made up of two masses of widely different ages. Haleakala probably ceased activity at about the same time as Mauna Kea. The windward, northern face of Haleakala, like that of all the Hawaiian mountains, receives torrential rainfall (400 inches per annum) and is densely covered with jungle forest. The leeward, southeastern slopes are conspicuously arid and barren. In its geological and botanical aspects Haleakala is much more closely related to Kea and Loa on Hawaii

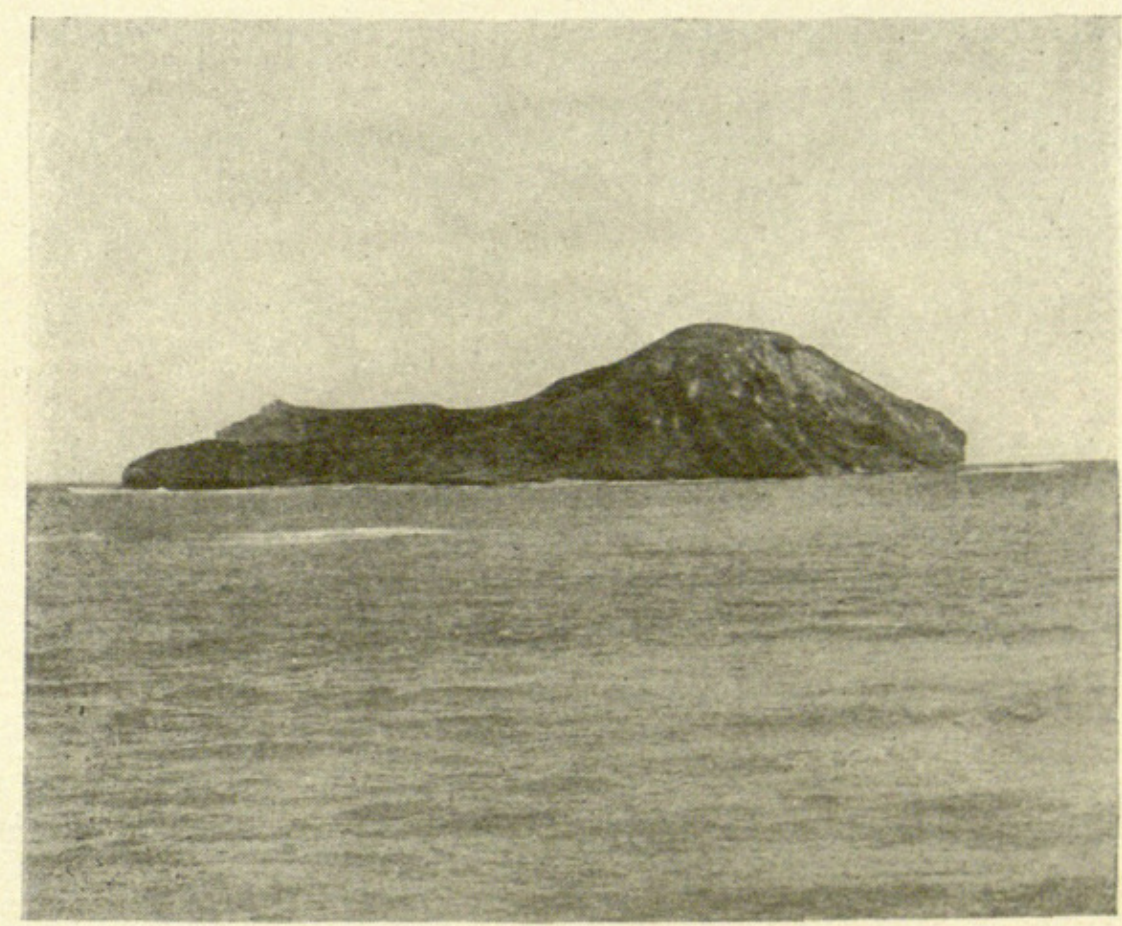

FIG. 5.-Manana or Rabbit Island, deeply eroded tufa cone, isolated as small barren islet off windward coast of Oahu, near Maka-pu'u Point; about $2200 \mathrm{ft}$. long and $400 \mathrm{ft}$. high, separated from main island by channel of I mile; vegetation sparse and stunted, no arborescent vegetation.

than to its associate West Maui. It is separated from Hawaii by a relatively narrow channel, 26 miles wide and 1032 fathoms deep. From the standpoint of this paper it will be considered as one of the Kea, Loa, Hualalai family.

THE FOUR GREAT MOUNTAIN MASSES.-These four great volcanic mountains, Haleakala, Kea, Loa, and Hualalai, closely resemble each other in a number of important ecological particulars: (I) their summits rise $8000-14,000 \mathrm{ft}$. above sea level and are frequently covered with snow; (2) there is a large treeless zone on the summit of each; this is most extensive on Loa, Kea stands next, then 


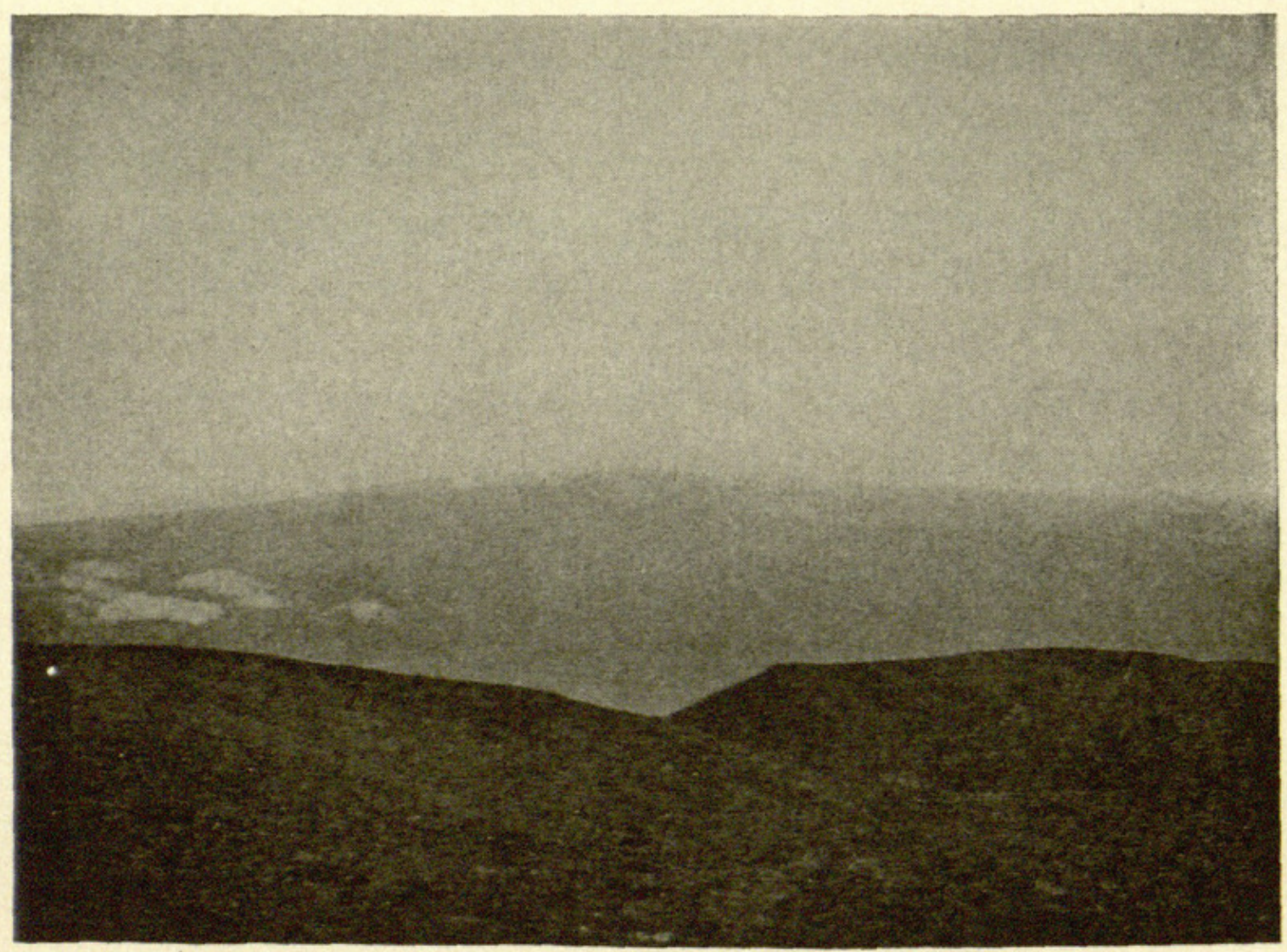

Fig. 6.- Summit and upper slopes of Mauna Loa as seen from summit of Mauna Kea; note very gentle slopes of Loa, and two cinder cones (explosive vents) in foreground.

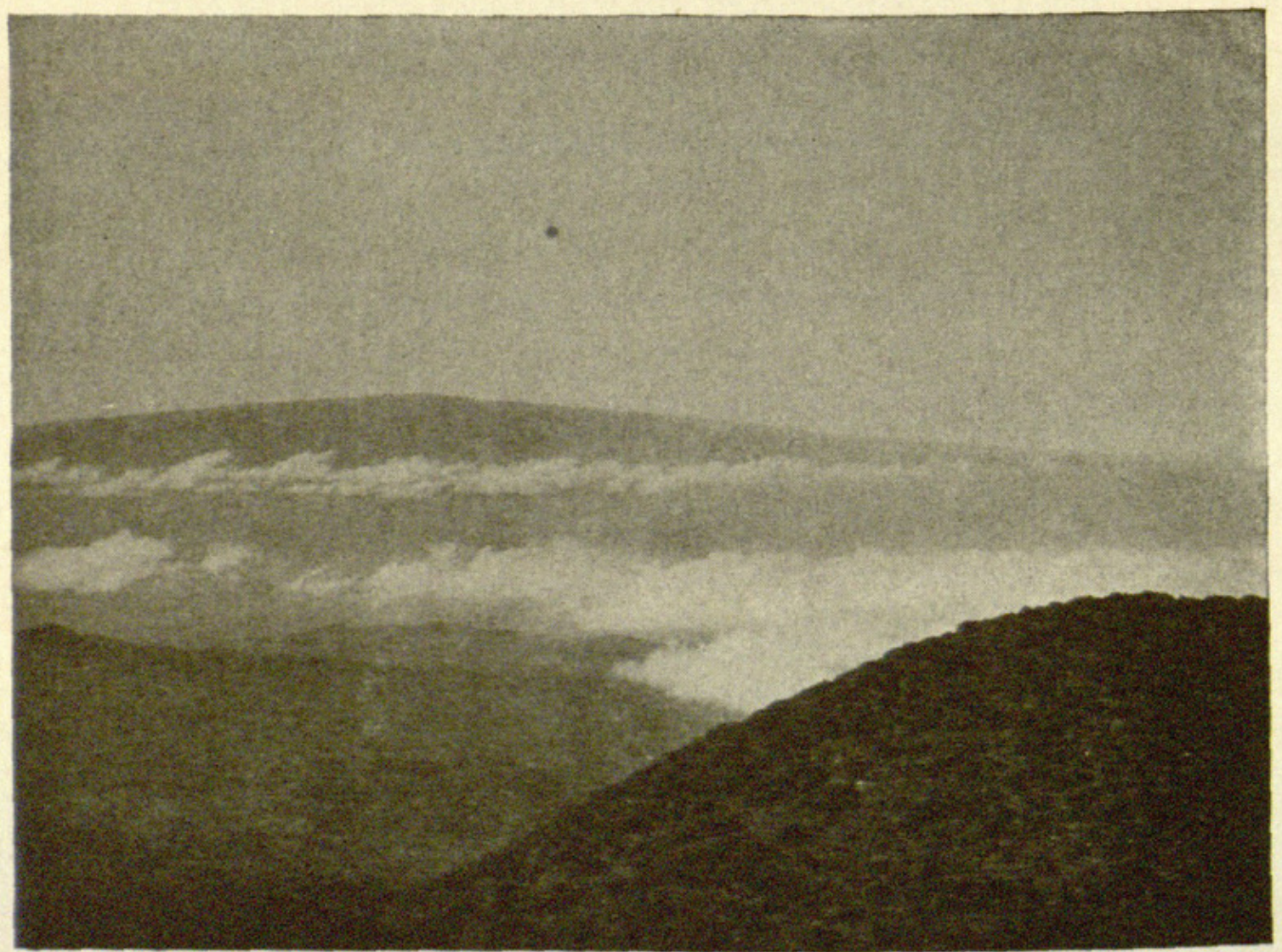

Fig. 7.-View of Loa from summit of Hualalai; clouds lying at elevation of $7000-8000 \mathrm{ft}$.; note xerophytic vegetation in foreground. 
Haleakala, and lastly Hualalai, the smallest of the four mountains; (3) the summits are marked by volcanic vents; either an active crater (Loa); or an extinct caldera (Haleakala); or great numbers of cinder cones (Kea); or by innumerable pit craters and cinder cones (Hualalai); all of these are large and tangible evidences of the earth forces by means of which the mountains were built up to their present height; (4) the mountains rise directly and gradually from the sea, without intervening lowlands or plateaus; (5) the

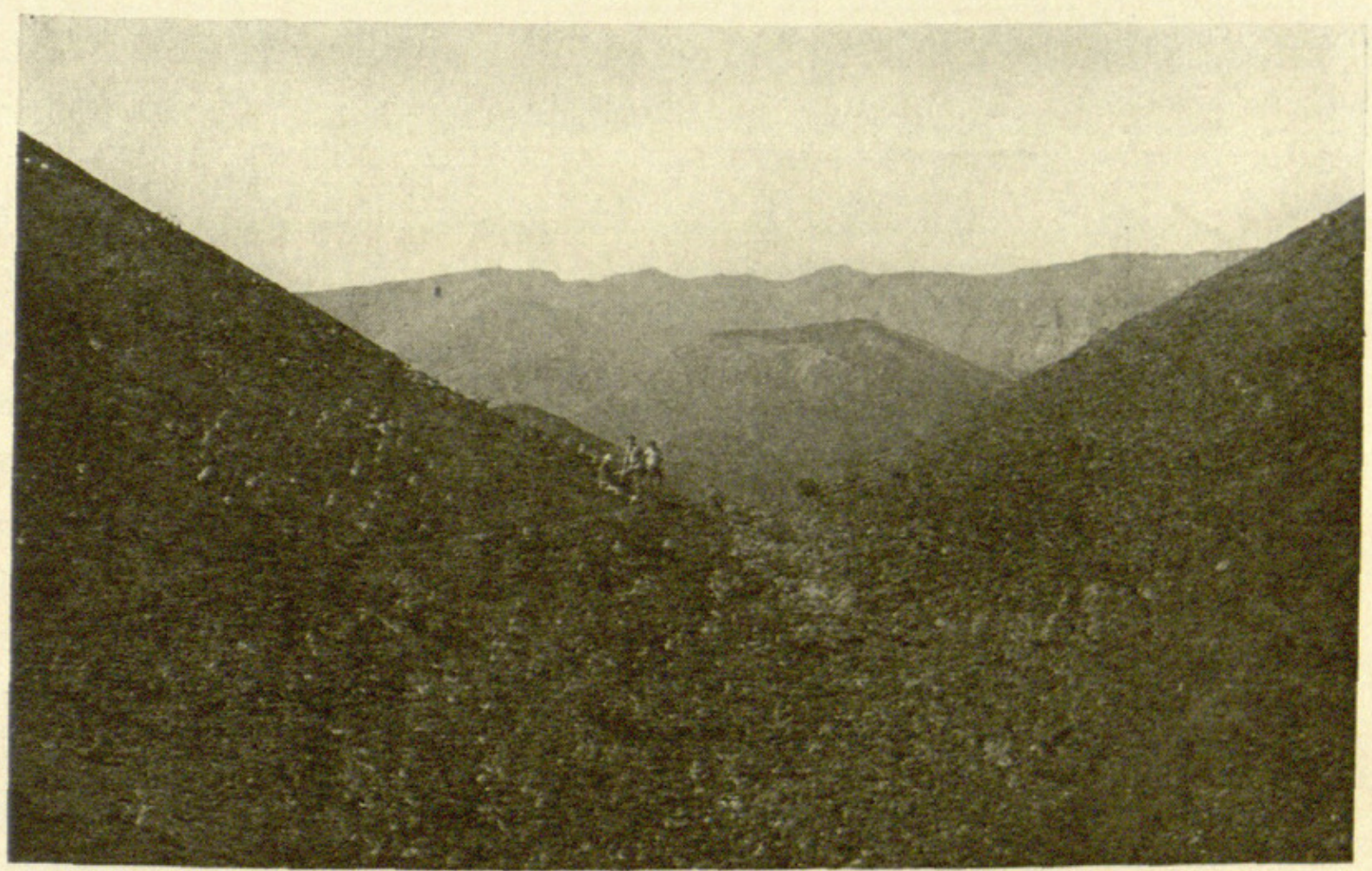

Fịg. 8.-Cinder cones on floor of Haleakala caldera; at extreme upper left are some silver sword plants (Argyroxiphium sandwicensis var. macrocephalum).

slopes and flanks of each mountain are covered by thick blankets of lava, cinders, and ash, which in the arid summit and leeward regions have undergone little or no erosion; (6) each mountain has a lower windward region which receives heavy precipitation; this rain, amounting to several hundred inches per annum in many localities, has caused the rapid decay of the lava flows in these zones and has covered the flows with luxuriant rain forest; the original flow structure is obliterated beneath heavy beds of soil and vegetation. This paper does not include the humid areas. 


\section{Cinder cones}

The slopes and summits of all four of the great mountains are thickly sprinkled with cinder cones (fig. 9). These vary in height from 200 to rooo ft., with very steep slopes of $30-40^{\circ}$. They are composed of volcanic ash, cinders, scoria, and other ejecta, and are frequently strewn with volcanic bombs and other lava blocks. These cones are most numerous on Kea and Hualalai; they are plentiful in the caldera of Haleakala and on the leeward slopes, and are by no means infrequent on the broad flanks of Loa. Many of these cones are more or less completely covered with vegetation

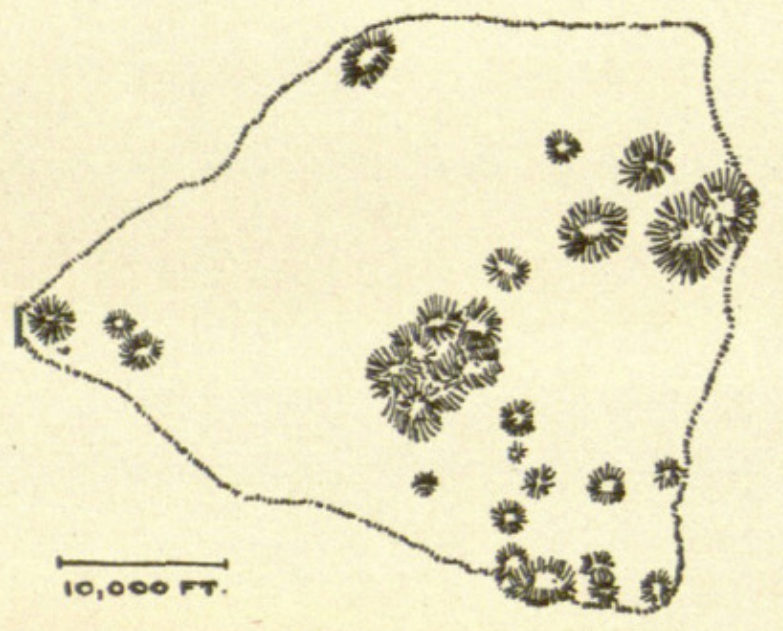

Fig. 9.-Summit plateau of Mauna Kea, showing numerous cinder cones; these explosion cones are abundant on all high mountains of Hawaii, from sea level to summit regions.

gigantic pits of Kilauea and Loa. The pits of greatest botanical interest are those of intermediate size, namely, I00-300 yards in diameter and of similar depths. There are many pits so deep and narrow that no floor is visible from the rim.

The pit craters occur indiscriminately in the rainy forest zones and on the barren slopes and summits. In the former case they are densely filled with trees and jungle litter; their mouths are often hidden by vines and other vegetation, and they constitute a serious menace to the traveler and to livestock. Those that occur in the arid sections are of particular botanical significance, as their steep walls prohibit invasion by cattle and goats, and the vegetation within them is unmolested. Thus they constitute botanical 


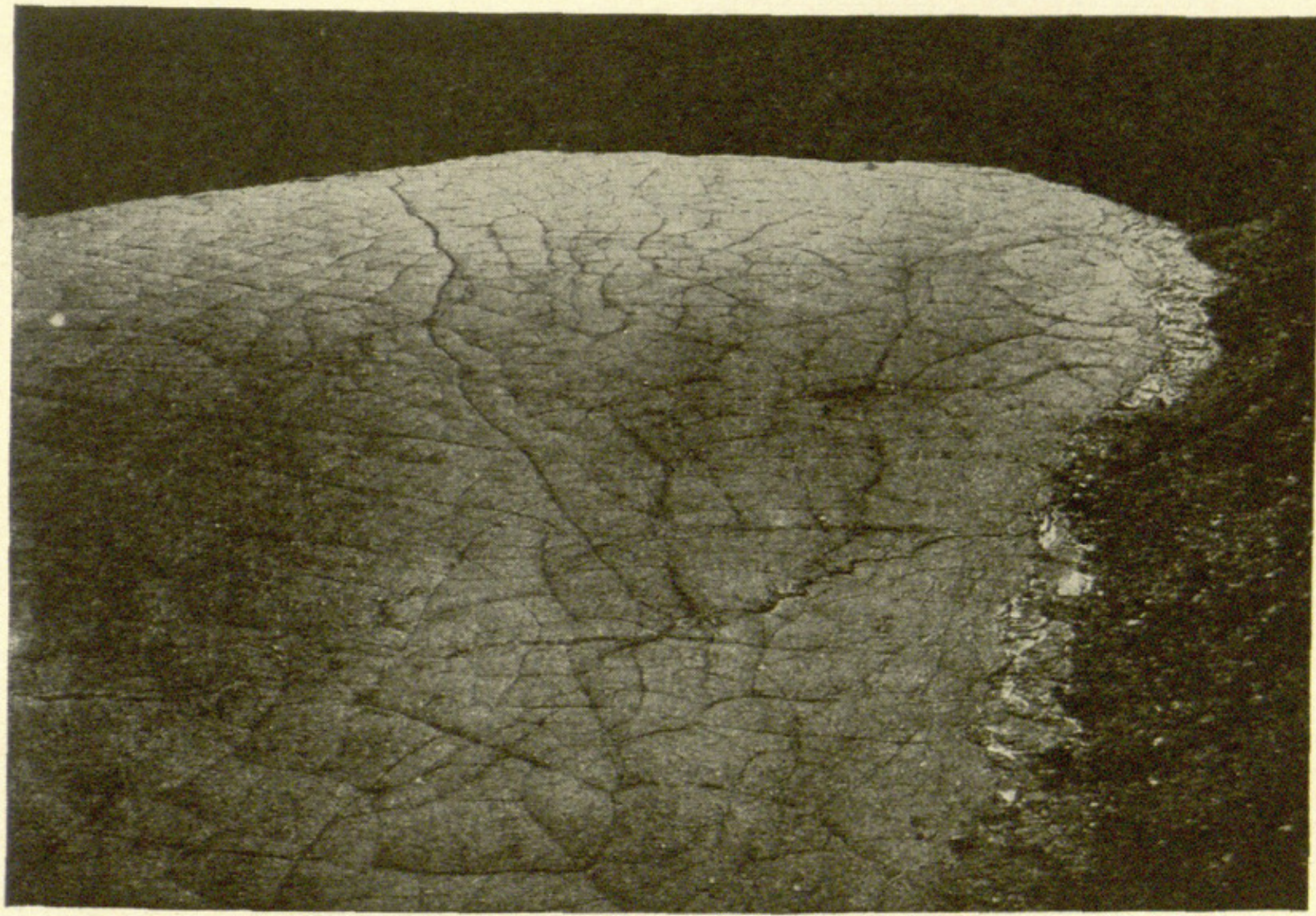

FIG. I0.-Floor of pit crater, close to Kilauea, fissured in mosaic manner with remarkable regularity; although nearly 40 years have passed since last eruption, there has been practically no plant invasion in this crater, due to its unfavorable situation.

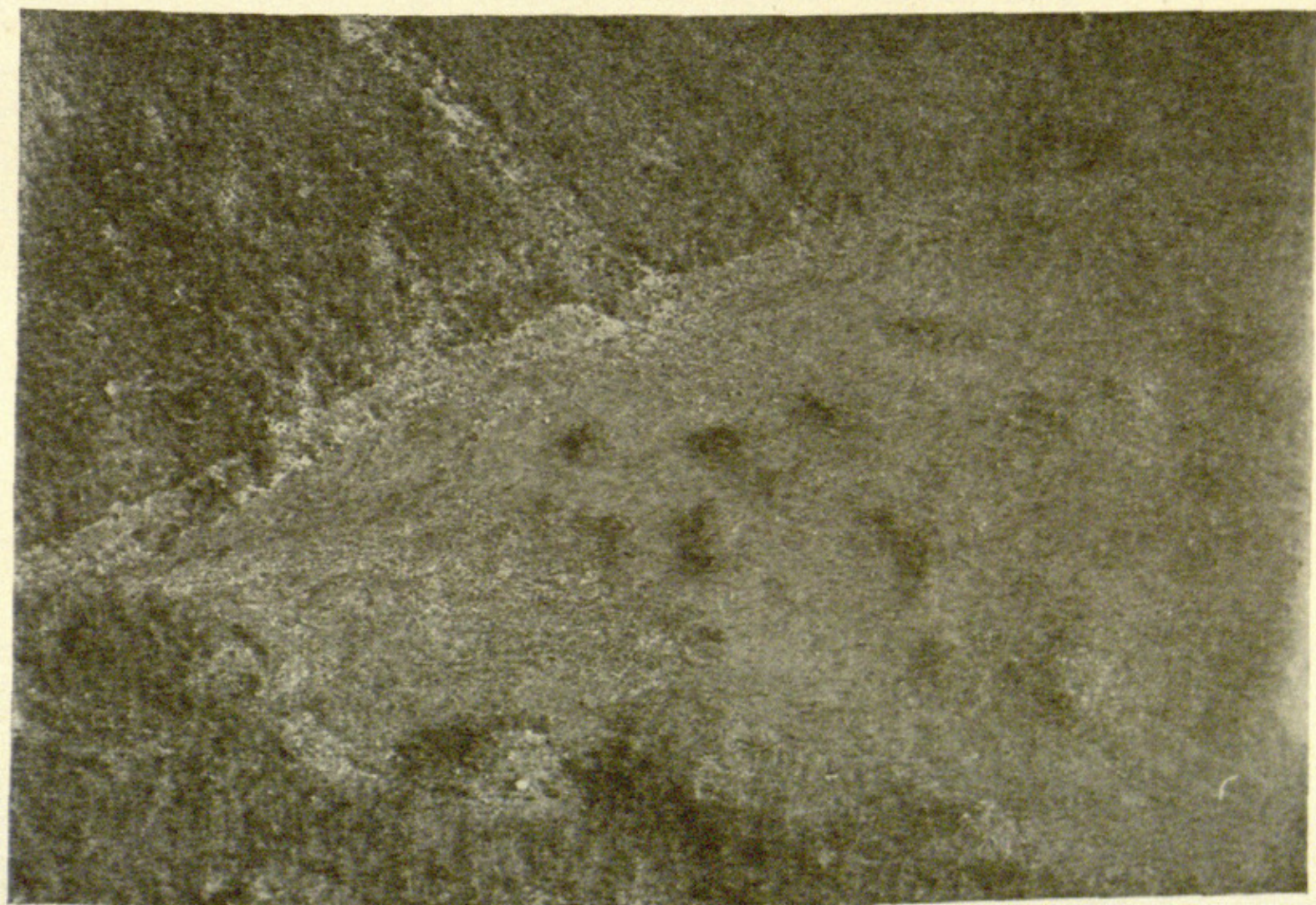

FIG. II.-Floor and wall of pit crater close to Kilauea, largely covered with pa-hoe-hoe; walls covered with Metrosideros polymorpha, 10-20 ft. high. 
oases in otherwise barren country and may be compared with the kipukas in the $a-a$ flows. Many remnants of the primitive flora are today making their "last stand" in these tiny areas where they are protected from wild livestock, the greatest enemy of the indigenous vegetation. Finally, the conditions of shade and moisture

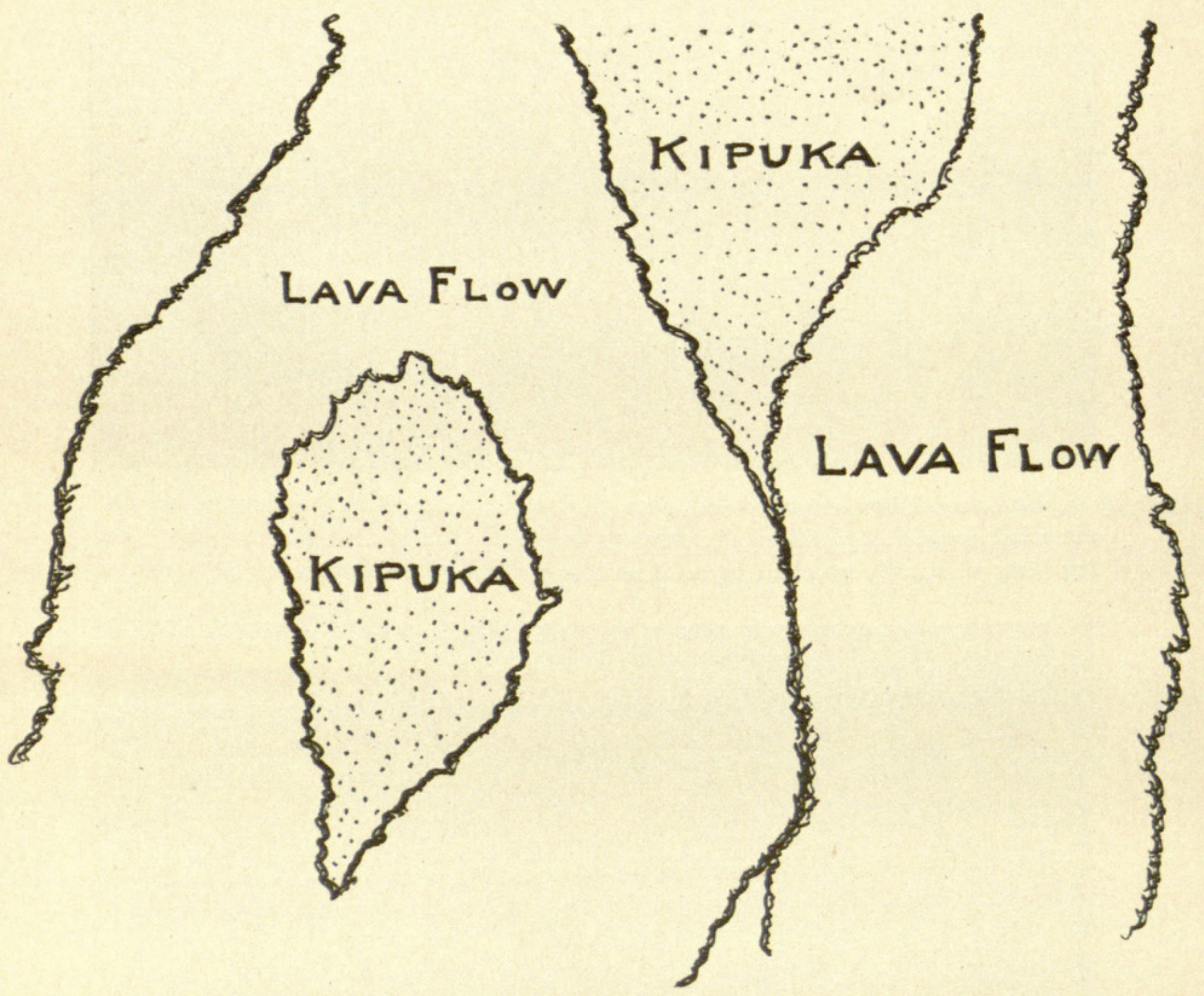

FIG. 12.-Diagram illustrating formation of kipuka in midst of lava fields.

are more likely to be favorable in the pits than on the exposed open lava flows, and the plants in the pits exhibit more normal growth forms than those in the open.

KIPUKAS.-This Hawaiian word, meaning an oval hole or depression, is a convenient designation for small areas that, owing to minor topographical irregularities, have escaped being covered by the lava flows which surround them (fig. I2). The flow may be 
split or deflected so that these small patches of forest remain unscathed. Like the pit crater, the kipuka is often a botanical garden in the midst of an arid waste land.

The lava which surrounds the kipuka, and which may be I $^{-}$ $30 \mathrm{ft}$. higher than the floor of the latter, serves as a protection from wild cattle and goats. The kipukas frequently contain a very rich flora, a remnant of the original forest cover. These patches are usually of very limited area, not more than 2 or 3 acres, and are sharply limited by the impinging lava beds. The soil within the area is usually deep, black, and rich, and of great antiquity. There are hundreds of these kipukas on the lower slopes of the great Hawaiian volcanoes, but only those in the arid regions retain their individuality. Those in the humid regions are hidden under the rain forest.

PUU WAA-WAA.-An ancient cone of minor topographical importance, but of extreme interest from the standpoint of the geological and botanical history of the archipelago, is Puu Waawaa, in North Kona, Hawaii. This cone is about 6 miles north of the summit of Hualalai, near the Loa flow of 1859 . Its elevation is about $3300 \mathrm{ft}$., above sea level. It is $500 \mathrm{ft}$. high, with steep, deeply fluted sides. The numerous erosion ravines which radiate from the summit and produce this corrugated appearance (the native name means "fluted hill") are 50-75 ft. deep. The cone is composed of volcanic ash and cinders, and exhibits the quaquaversal structure of the typical explosive cone. It has been deeply encircled by lava streams from Hualalai and Loa.

Studies by $\mathrm{CROSS}^{2}$ of the lavas which underlie Puu Waa-waa have demonstrated that these lavas are trachytic, and vastly older than the basaltic lavas which now largely cover them. This hill is undoubtedly a vestige of an ancient island mass now submerged beneath newer lava. Botanical explorations by Rock have strikingly confirmed the antiquity of the Puu Waa-waa region as contrasted with the much younger regions which surround it. Many evidences of a primitive flora have been found, a flora that has largely disappeared from other portions of this

${ }^{2}$ Cross, Whitman, An occurrence of trachyte on the island of Hawaii. Jour. Geol. 12:510-523. 1904. 
island. The Puu Waa-waa region, like some of the pit craters and kipukas, is a botanical oasis in the midst of a desert and harbors much material of unquestionable antiquity.

VolCANIC DUST.- In order to treat comprehensively the ecological aspects of the lava regions, it is necessary to include a statement concerning volcanic dust (fig. 13). The Hawaiian volcanoes have

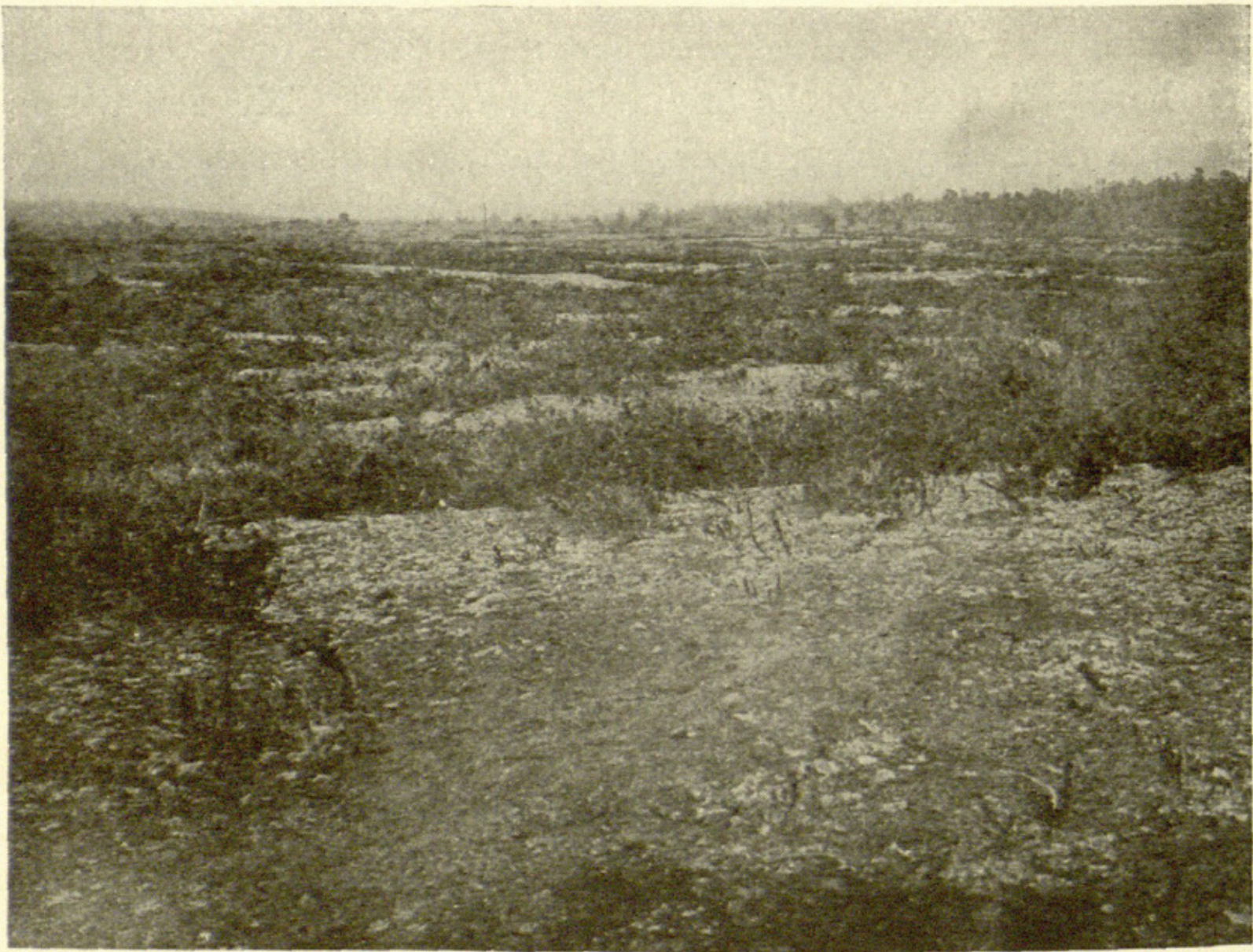

FIG. I3.-Pumice fields, Kilauea volcano; chief plants, Metrosideros polymorpha and various xerophytic species; white patches in foreground, lichens; in distance, to right, is ohia forest, Metrosideros polymorpha.

been conspicuously quiescent in their activities during historic times; the outpourings of lava have been relatively gentle and non-explosive. There is much evidence, however, which indicates tremendous explosive eruptions at various periods in the history of the volcanoes, and at least one of these (Kilauea, I790) has fallen within historic times.

Among the most abundant of the varied products of these explosive eruptions, in the Hawaiian Islands as in the case of volcanoes generally, is volcanic dust. Extensive deposits of dust 
occur on the leeward slopes of Haleakala and in the caldera itself; on the leeward slopes of Kea and Loa; and great beds to the leeward of Kilauea. Perhaps the largest area is in the $\mathrm{Ka}-\mathrm{u}$ district, where, according to $\mathrm{HITCHCOCK},{ }^{3}$ it covers "an area of 300 sq. mi." It is not within the province of this paper to enter into any detailed account of these dust deposits, but two important floristic relations may be enumerated: (I) the obliteration of any vegetation that may have occupied the region previous to the deposit; (2) the thick layer of ashes, if rainfall or irrigation be sufficient, forms a rich and mellow soil and transforms what would otherwise have been lava waste land into productive country. The plantations and ranch lands of $\mathrm{Ka}-\mathrm{u}$ owe their origin to this. It may be pointed out, in conclusion, that similar deposits of volcanic ash, of great area and thickness, occur in Central America, Mexico, the Sierra Nevadas, the Great Basin, Utah, Montana, South Dakota, Nebraska, Kansas, Washington, Oregon, Alaska, Canada, and many other places.

\section{Ecological factors}

SLOPE.-There is considerable variation in the gradient of the various high mountains, but on the whole it is remarkably gentle. Loa has a deceptively gentle slope, averaging $4-6^{\circ}$ and not over $8^{\circ}$ at the steeper places. Its outline against the sky is that of a very much flattened dome, or "whaleback." The slopes of Kea and Haleakala are more abrupt, usually about $12^{\circ}$, but sometimes as high as $15^{\circ}$. Hualalai is the steepest of the 4 mountains, particularly near its summit, with an average slope of $14-18^{\circ}$. The cinder and ash cones have slopes which lie at the critical angle for material of this character, namely, 30 or $40^{\circ}$. The mountains are all relatively young and have not been carved by deep, precipitous-walled amphitheaters of erosion, as have the mountains of Kauai, Oahu, eastern Molokai, and West Maui.

Precipitation.-The only comprehensive records of rainfall in the Hawaiian Islands are those made by the United States Weather Bureau and the United States Hydrographic Survey. The records of the former are collaborated from the reports of

${ }^{3}$ Hrтснсоск, C. H., Volcanoes of the Hawaiian Islands, p. I53. 
about 50 observers, scattered at various points on the islands. As these observers are stationed in or near human settlements, and as these settlements are situated in regions of at least moderate rainfall, it happens that there are no records covering the areas which form the central theme of this paper. The great upper slopes of Loa, Kea, Hualalai, and Haleakala, having a total area much greater than that of the peripheral lowlands, are uninhabited waste lands and without meteorological data comparable to that of the agricultural lowlands.

The Hydrographic Survey, interested primarily in the rain sections and the streams, has naturally avoided the great arid and streamless areas which are considered in this paper. Hence it is not possible to present extensive tables showing accurately the precipitations on these arid districts.

It is necessary to emphasize the importance of the trade winds as the rain-bearing winds of the islands. These winds blow from the northeast almost continuously through a large portion of the year. The main axis of the archipelago lies from northwest to southeast, so that the islands lie across the path of the trades, and hence develop strongly differentiated windward and leeward climates. The warm trades sweep across vast stretches of ocean before reaching the islands, and are consequently saturated with moisture. Upon striking the cool mountain slopes very heavy precipitation ensues, often totaling several hundred inches. ${ }^{4}$ In this zone the luxuriant rain forest reaches its finest development. The leeward slopes, however, are robbed of this torrential rain; the winds that reach them are usually dry and parched, and the climate is arid or semiarid.

SNOw AND ICE.- The high mountains of Maui and Hawaii are often snow-capped. This is particularly true of Kea, literally the "white mountain," which is prevailingly snow-crowned from November to March and intermittently at other seasons. At the season of greatest snowfall the snow line often reaches down as low as $9000 \mathrm{ft}$.; at other seasons there are frequently extensive patches of snow at the higher levels. Near the extreme summit

4 The greatest annual precipitation officially recorded in the Hawaiian Islands is 56r inches, in r9r6, on Waialeale, Kauai, by the Hydrographic Survey. 
of Kea, at an elevation of $14,000 \mathrm{ft}$., is a small perennial pond, Wai-a'u, about $125 \mathrm{ft}$. in diameter. This pond is situated in an ancient crater basin and is fed by the melting snow. It is frozen during a major part of the year, even in midsummer. Ice occurs in the deep fissures and caverns in the neighborhood of the summits of Kea and Loa throughout the entire year, and during late winter it is relatively abundant.

Summit REgIONS.-The treeless character of the summits has already been mentioned. The timber line is very low, indeed unusually low as compared with that of mountains in other parts of the world. HALL's ${ }^{5}$ explanation so accurately summarizes the local conditions that it is reproduced herewith:

Elevation has put a sharp limit to the forests on the islands of Hawaii and Maui at from 6000 to $8000 \mathrm{ft}$. This leaves very large areas of Mauna Loa, Mauna Kea, Hualalai, and Haleakala devoid of forest, and they have always been so. The mountains of the other islands, being under $6000 \mathrm{ft}$., are forested to their summits. Six to $8000 \mathrm{ft}$. is a surprisingly low timber line, considering the favorable conditions of soil, moisture, and temperature which prevail at that altitude in Hawaii. The sufficient reason seems to be that the species composing the native forests are all representatives of the torrid zone, and in these islands, which lie right at the edge of the Tropics, find their limit at the low altitude named.

SEEPAGE.-The physical structure of the lava flow is such that seepage takes place with extreme rapidity, and in the typical flow country there is absolutely no surface water. This abnormally high percolation greatly heightens the physiological aridity of the lava as a substratum for plant life. Both the $a-a$ and the pa-hoe-hoe types of lava are highly ramified with crevices, caverns of all sizes, and long tunnels or lava "tubes." Thus a vertical section of the mountain would reveal a copiously spongy texture, with large caverns sloping toward the sea. DANA's ${ }^{6}$ account may be appropriately quoted in this connection:

Over the leeward sides .... where rains are infrequent, a black desert everywhere prevails, and there is, with rare exceptions, only an alternation between the smoother fields of cooled lava and the rougher districts of scoria. Yet over the barest fields there is always a sprinkling of verdure, growing

${ }^{5}$ HALL, W. L., Forests of the Hawaiian Islands. 1904 (p. I6).

${ }^{6}$ Dana, J. D., Geol. U.S. Explor. Exped. xо:1849 (pp. 159-160). 
from the many crevices or cavities. Whatever showers fall on this portion of Hawaii are at once absorbed by the cavernous rocks; and consequently through its whole extent, south and east, there are not two permanent streamlets. Water is to be found only in caverns; and often a journey of some miles must be taken by the villager to supply himself for his daily consumption. All the caverns about the lower parts of the mountains have been well explored for this necessary of life.

There is probably no other region in the world where rainwater disappears with greater rapidity than on the leeward slopes of the Hawaiian Mountains. The honeycombed lava flows swallow it up, and convey it to the sea through deep subterranean channels. Thus the aridity of the lava country is compounded by 3 factors: low precipitation, high evaporation, rapid percolation.

EVAPORATION.-An ecological factor of probably greater importance than either precipitation or percolation is that of high evaporation, which characterizes the Hawaiian flows, as it does all arid regions. This very high evaporation is strongly productive of xerophilous structures and is probably more potent than any other single factor.

\section{The lava flow}

In order to elucidate the structural peculiarities of the lava country as related to plant life, a brief synopsis of the formation of a typical flow may be presented. This is adapted from Hоввs's account.

The lava either quietly melts its way to the surface at the time of outflow, or else produces one or more fissures for its egress to the accompaniment of vigorous local earthquakes. In either case, if the lava issues at a point far below the crater, the hydrostatic pressure causes gigantic lava fountains to arise at the point of outflow. The fluid, incandescent rock shoots up to heights which range from 200 to $700 \mathrm{ft}$. or more above the surface. In the $185^{2}$ eruption of Loa a fountain of lava $1000 \mathrm{ft}$. broad rose to a height of $700 \mathrm{ft}$. A certain proportion of this fluid lava is sufficiently cooled to consolidate while traveling in the air, and upon falling it builds up a cinder cone. This cone becomes a location

${ }^{7}$ Hoвss, W. H., Earth features and their meaning. Macmillan. I9I2 (pp. IroIII). 
monument at the place of discharge. Cones of this sort are plentiful on the slopes of Loa and Kilauea. From this outlet the lava begins its journey down the slopes of the mountain. The surface quickly freezes over and produces a tunnel, beneath the roof of which the fluid lava flows with comparatively slow further loss of heat. It empties its own tunnels, and in this way the long lava tubes, beneath the flows, are formed. The great lava streams that flow down the side of Loa sometimes attain a length of nearly 50 miles, and occasionally enter the sea. They are often 2 or 3 miles broad. DANA estimated the $185^{2}$ flow to contain over 10,500,000 $\mathrm{cu}$. ft. of lava. The low angle of slope presented by the flanks of the mountain, and its nearly flat summit, are due to the tendency of the sheet of liquid rock to travel far and spread widely before cooling. It is by the successive additions of such sheets that the mountain has been built up.

It is of interest to note RUSSELL's ${ }^{8}$ statement concerning the great Columbian lavas of the Northwest, which cover an area of $200,000-250,000$ sq. miles. He points out that this is "not one vast flow, but is composed of many independent sheets, which are sometimes separated by land surfaces containing the stumps of trees and even huge trunks buried in lapilli and now thoroughly silicified."

SURFACE OF LAVA FLOWS.-There are two principal types of lava forming the Hawaiian flows, which determine the general surface and structure of the flow: $P a$-hoe-hoe, the native word for smooth or shining, designates the smooth pavement type (figs. $I_{4}-I_{7}$ ). The crust is glassy and frequently quite brittle. Hummocks or mounds are frequent, due to the rapid cooling of the surface. Some of these mounds are quite small, others may be 30-40 ft. high and twice as long, the thick crustal layers being broken and heaped like "pack" ice. The surface of the pa-hoe-hoe is commonly of a ropy or festooned pattern. The wrinkles and furrows have their convex arcs downstream, as the velocity is greater in the center than at the sides. As the smoother, pavementlike parts of the flow cool, vertical cracks develop in every direction, forming a coarse network or mosaic pattern. The distance

${ }^{8}$ Russel., I. C., Volcanoes of North America. Macmillan. 1897 (p. 250). 
between these cracks is commonly every 2 or $3 \mathrm{ft}$. in all directions. The flow is thus broken up into irregular polyhedral blocks, which tend to separate under weathering and gravity. In old flows these cracks may become several inches wide and are commonly utilized by plants as growing places. The fresh pa-hoe-hoe is shining jet

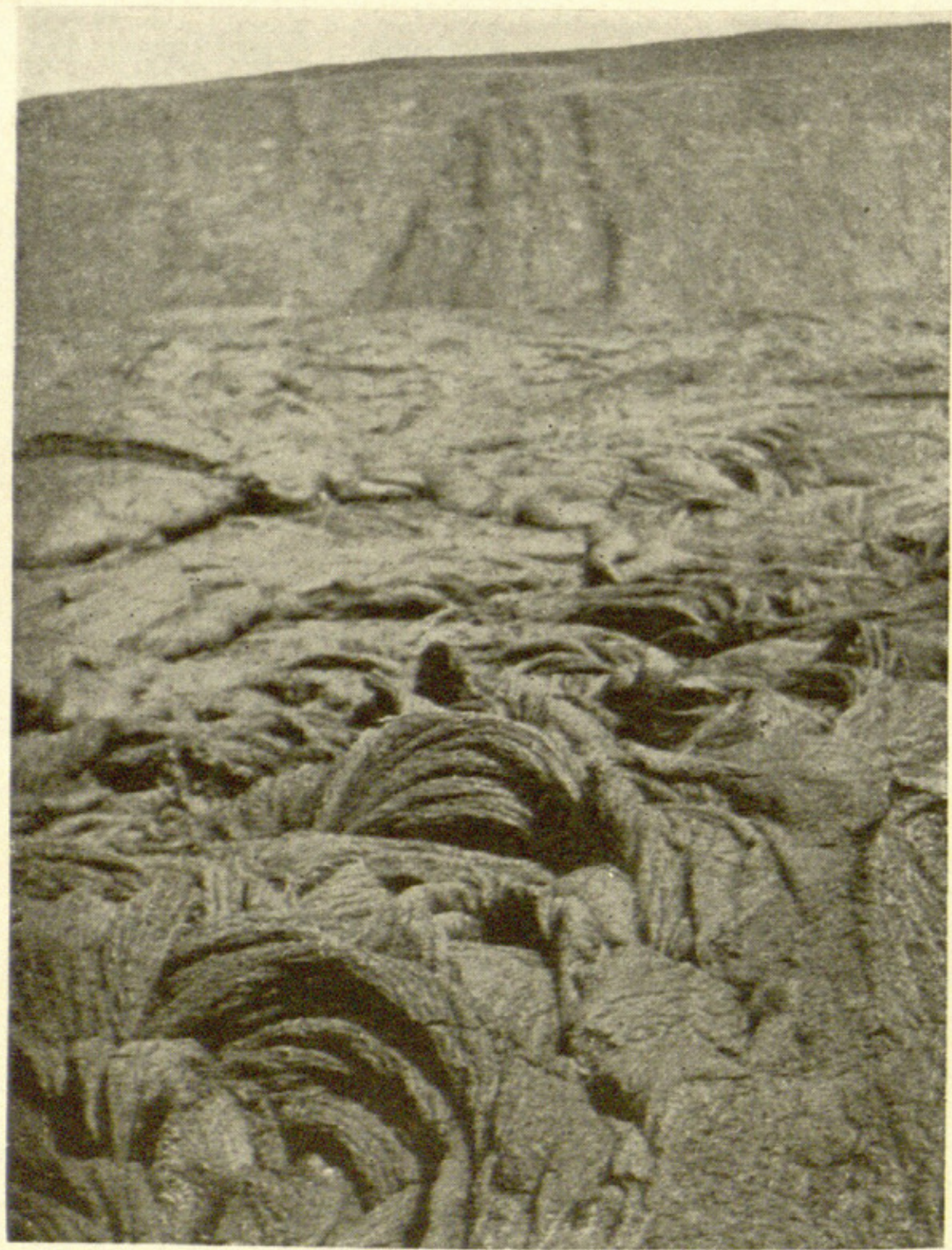

FIG. I4.-Close view of ropy or festooned pa-hoe-hoe on floor of Kilauea; note concave upper faces of festoons in which seeds and spores are caught and plant life first established.

black and in arid situations retains this appearance for an indefinite period. Under humid conditions, however, it weathers rapidly and becomes brown or reddish, due to the oxidation of its high iron content. On the pa-hoe-hoe fields the plant life occurs chiefly in the furrows or wrinkles of the ropy areas and in the numerous fissures that are abundant in the surface of the smoother areas. 


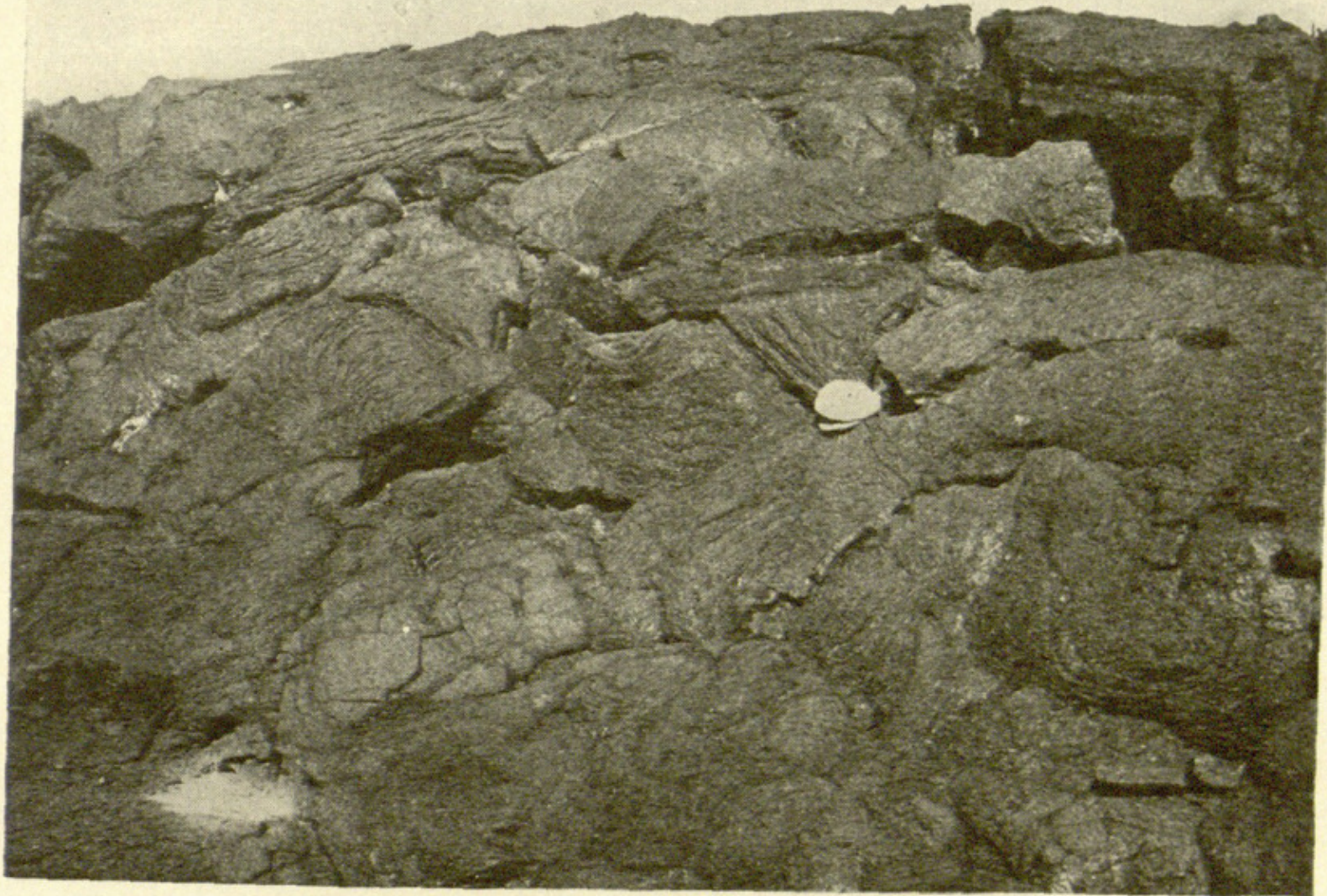

FIG. 15--Mound of pa-hoe-hoe lava, on floor of Kilauea crater, composed of heavy slabs of vesicular lava; surface conspicuously festooned or ropy.

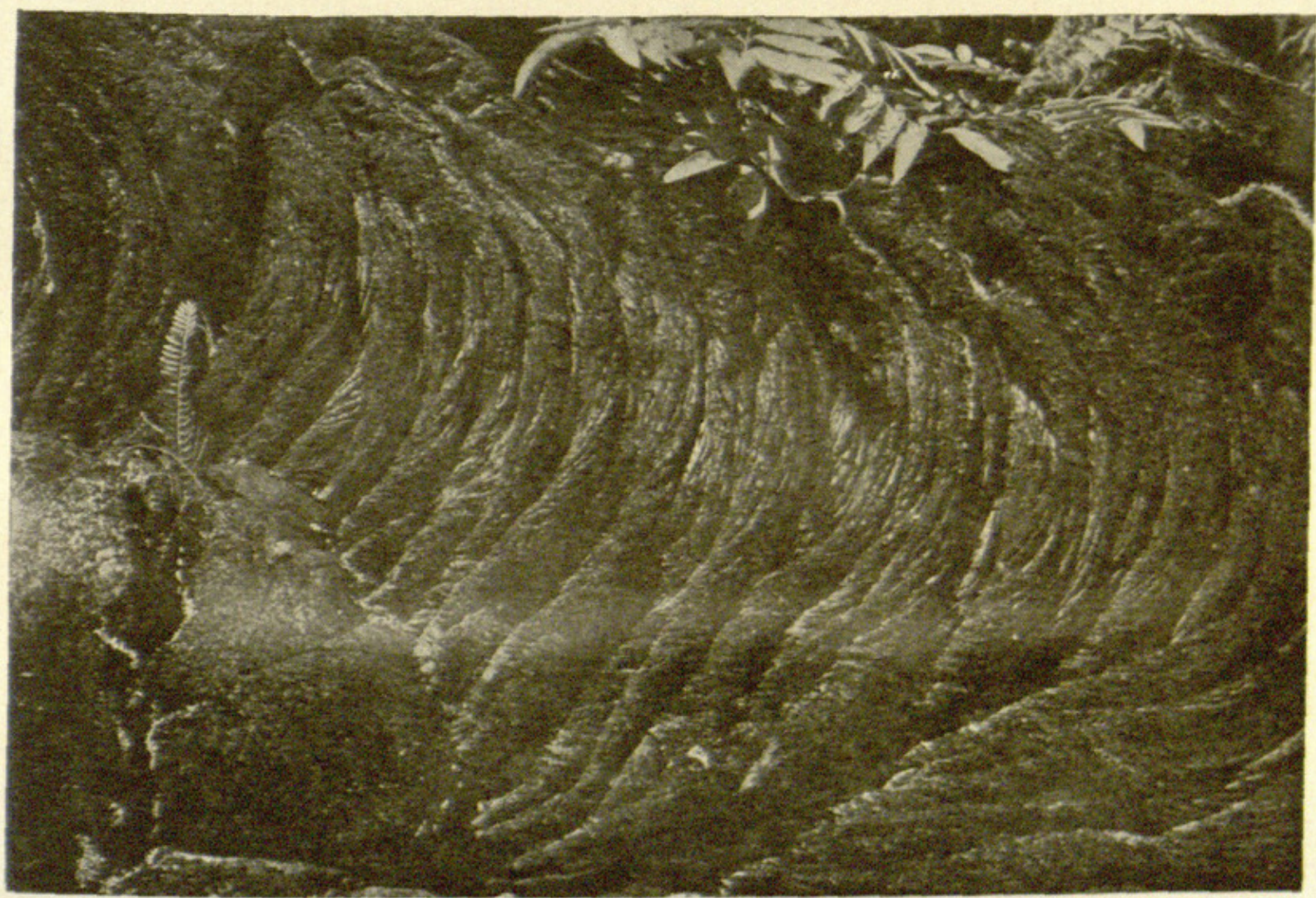

FIG. I6.--Surface of festooned pa-hoe-hoe; note abundant lichen growth both in crevices and on protuberances; fern is Polypodium pellucidum. 
$A-a$ is exceedingly rough lava (fig. I8) composed of incoherent, bristling spiny blocks of all sizes, like gigantic clinkers. DANA says (loc. cit., p. I62):

They look as if the mountain had been shattered to a chaos of ruins. The fragments vary from I to $10,000 \mathrm{cu}$. $\mathrm{ft}$. or from a half bushel measure to a house of moderate size. They are of all shapes, often in angular blocks, sometimes in slabs, and have a horrible roughness beyond conception, points and angles standing out in every direction; they lie together, touching only by their edges or points, leaving deep recesses everywhere between them.

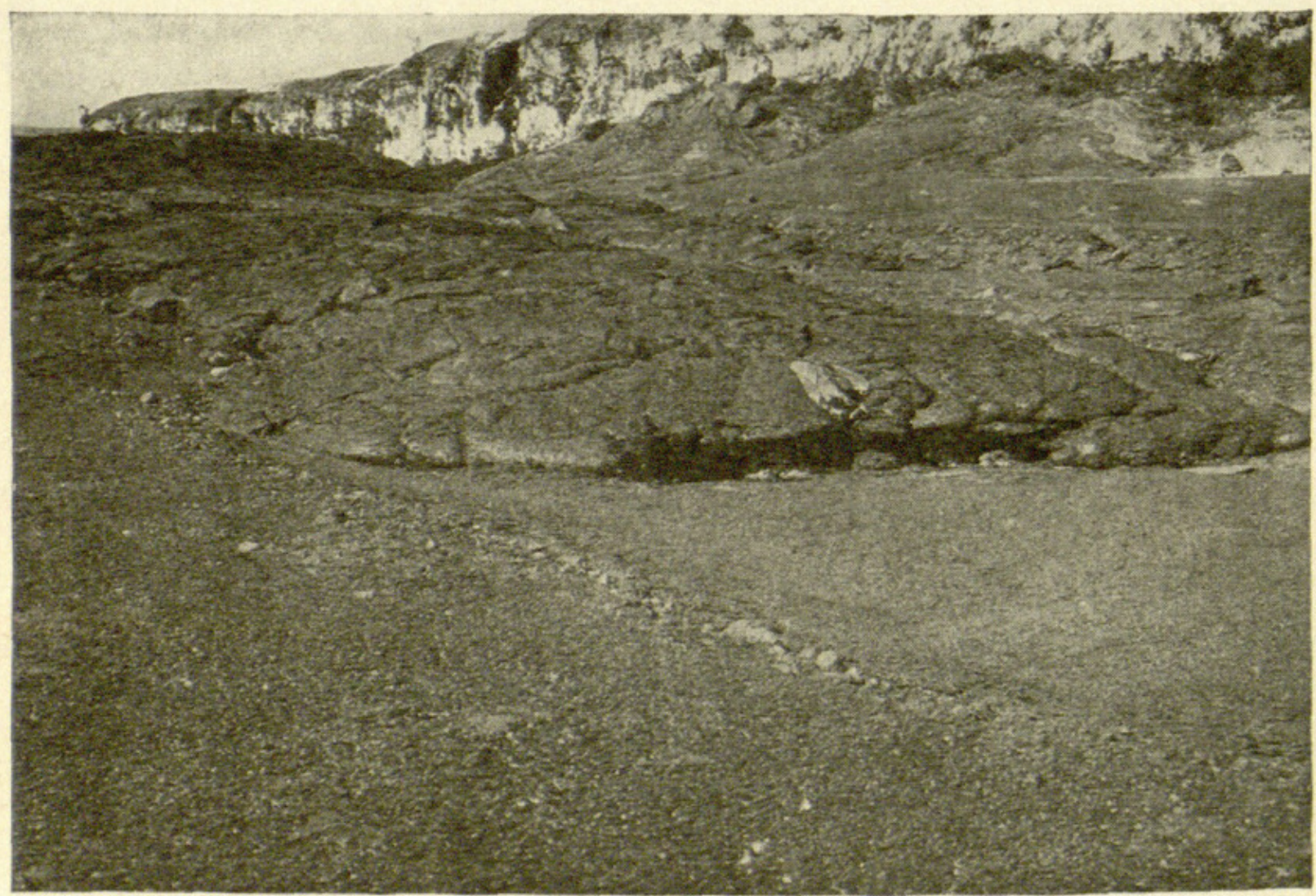

Fig. 17.-Front or end of pa-hoe-hoe flow in crater of Kilauea; note smooth character of surface and lobular margin; plants here and there along margin are Vaccinium reticulatum.

The beds are $30-60 \mathrm{ft}$. thick, with innumerable cavities between the blocks. On very old $a-a$ flows the blocks and finer material have settled somewhat, rendering the entire mass more compact; the surface material is also less spiny. $A$ - $a$ flows are so rough as to be practically impassable by man or beast, and in traveling across the lava wastes one is compelled to make long detours to avoid them. The sharp cutting edges quickly destroy even the 
heaviest leather boots. Horses, cattle, and goats use the pa-hoe-hoe as natural roadways but refuse to cross the $a-a$. It is due to this impassability of the $a$ - $a$ that plants growing upon it, or in areas surrounded by it, are protected from the devastations of herbivorous animals. Thus portions of the primitive flora have been preserved in regions where they would have otherwise been de-

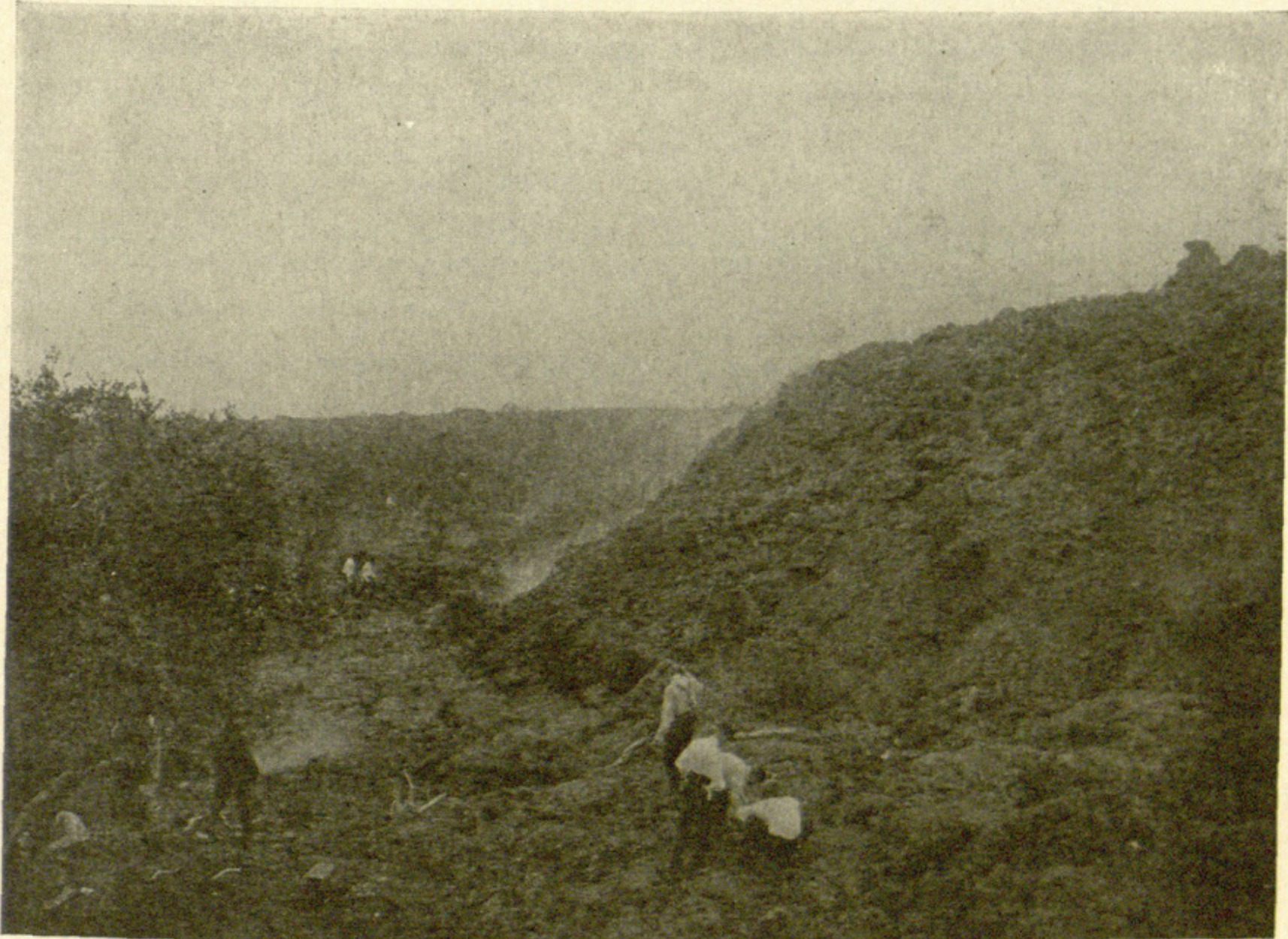

FIG. I8.-Front or end of I9I7 flow, which issued from flanks of Loa, composed of $a-a$, flowing over older pa-hoe-hoe; smoke arising from various portions of flow; note angular fragments of which $a-a$ is composed, tree at lower left is Metrosideros polymorpha.

stroyed by wild cattle and goats. $A-a$ lacks the glistening appearance of pa-hoe-hoe and is usually dark chocolate brown instead of black. Sometimes the reddish tint is quite pronounced. The brown and red are due to the high iron content, which characterizes all the Hawaiian lavas.

Chemical composition of LAva.-The following table illustrates the chemical composition of a typical Hawaiian basaltic 
lava and is selected from a large series collected by H. S. WASHIngton (U.S. Geol. Survey, Professional Paper no. I4). The

\begin{tabular}{|c|c|c|c|}
\hline & $49.0 \mathrm{I}$ & $\mathrm{K}_{2} \mathrm{O} \ldots$ & 0.80 \\
\hline $\mathrm{Al}_{2} \mathrm{O}_{3} \ldots \ldots \ldots \ldots$ & I6. 29 & $\mathrm{TiO}_{2} \ldots \ldots \ldots \ldots$ & $3 \cdot 8$ \\
\hline $\mathrm{Fe}_{2} \mathrm{O}_{3} \ldots \ldots \ldots \ldots$ & 7.61 & $\mathrm{P}_{2} \mathrm{O}_{5} \ldots \ldots \ldots \ldots \ldots$ & \\
\hline $\mathrm{FeO} \ldots \ldots \ldots \ldots \ldots$ & 4.89 & $\mathrm{MnO} \ldots \ldots \ldots \ldots$ & \\
\hline $\mathrm{MgO}$. & 3.62 & $\mathrm{SO}_{3} \ldots$ & \\
\hline $\mathrm{CaO} \ldots$ & 9.79 & & \\
\hline $\mathrm{Na}_{2} \mathrm{O} \ldots$ & 3.8 & $\mathrm{CuO} \ldots \ldots \ldots \ldots$ & \\
\hline
\end{tabular}

soils derived from the weathering of these basaltic lavas are very different from those common on the mainland of the United States. Burgess ${ }^{9}$ states as follows:

They are primarily basic in composition, whereas those of North America, for example, are acidic. The bases or framework of Hawaiian soils are the oxides of iron and aluminum, whereas the basis of mainland soils is silica. A glance at the following table will show these great differences better than words can express them. These figures represent averages of large numbers of soil analyses made by the "absolute" or "fusion" method. The column marked "Mainland soils" represents averages of soil analyses from almost every state in the Union and from provinces in Canada. The column labelled "Hawaiian soils" gives average figures for over 300 composite samples of soil from the leading types on all of these islands. All of these analyses were made here and under similar conditions.

\begin{tabular}{|c|c|c|}
\hline & Hawaiian soils & Mainland soils \\
\hline 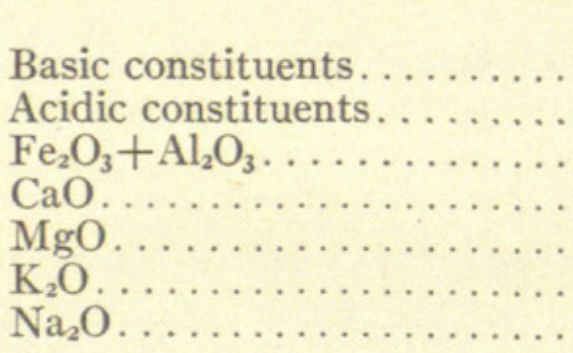 & $\begin{array}{r}\text { Per cent } \\
63.717 \\
36.45^{8} \\
59.240 \\
0.698 \\
1.242 \\
0.737 \\
1.420\end{array}$ & $\begin{array}{l}\text { Per cent } \\
\text { I } 8.980 \\
81.014 \\
13.250 \\
0.830 \\
0.771 \\
1.622 \\
2.229\end{array}$ \\
\hline
\end{tabular}

The prevailing low summit temperatures have already been noted. The annual mean temperature of Mauna Loa at the timber line is estimated by the United States Weather Bureau as $50^{\circ} \mathrm{F}$. and the summit temperature as $35^{\circ}$. The Bureau states "in the 
absence of actual observations in the higher levels, a temperature decrease of $\mathrm{I}^{\circ} \mathrm{F}$. is assumed in each $320 \mathrm{ft}$. of ascent." ${ }^{\mathrm{r}}$ The annual mean summit temperature of Kea is given as below $30^{\circ}$. It should be emphasized that very much lower temperatures than these prevail during a considerable portion of the year, especially at night, and are accentuated by the high winds. During the brilliant cloudless day the black lava sheets absorb great quantities of heat, and the aerial temperatures near the ground become very high. At nightfall, however, a very rapid chilling of the air ensues, and the thermometer drops in a few hours to the neighborhood of freezing point. This sudden drop is familiar to all who have ascended the high peaks. This wide diurnal range of aerial summit temperatures is in striking contrast to the equable and monotonously invariable temperatures of the littoral regions.

Temperatures of LAVA AND CINDER FIELDS.-Reference has already been made to the low temperatures which prevail at the summit regions. Another phase of this extremely interesting ecological factor remains to be considered, namely, the comparatively high temperatures which characterize the lava and cinder fields themselves during the daytime. All of these volcanic deposits are black or very dark in color. They absorb vast quantities of heat during the uninterrupted diurnal period of insolation. Those who have traveled across the lava waste lands well know that by the middle of the afternoon the surface of the rock is distressingly hot. The surface, the rock layer immediately below it, and the aerial layer immediately above it have temperatures much higher than the prevailing aerial temperatures. This condition is similar to that reported by investigators of other desert regions. MACDougaL II notes that "the sandy soil around the roots of small herbaceous plants in the Grand Canyon, Arizona, . . . . exhibited temperatures as high as $148^{\circ} \mathrm{F}$." It is to be further noted, as MacDougal states (loc. cit., p. 77), that "these extreme temperatures are met only by the roots of species spreading in the surface layers of the soil." Deep-rooted species are not so likely to be affected.

ro U.S. Weather Bureau, Hawaii Station, Ann. Rept. I9r5 (p. 2).

"I MacDougal, D. T., Botanical features of American deserts, p. 82. 
No thermograph records are available for subterranean temperatures in the Hawaiian lava flows, but such will very likely correspond closely with the results obtained by Cannon. ${ }^{\mathrm{I} 2}$ In his study of the root relations of desert plants at Tucson, an almost continuous record was made of the soil temperatures at a depth of $15 \mathrm{~cm}$. for the 5 years I905-1909. CANnON states:

The record shows an undulating record of which the curve crests correspond to the warmest for each day, and the depressions the coldest. The crests .... are remarkably uniform in height, as also the depressions are uniform in depth. The difference between the crests and the depressions is about $8^{\circ} \mathrm{F}$., with $12^{\circ}$ as the greatest variation. . . . Owing to the lagging of the soil temperatures, as compared with those of the air, the maximum is not attained until about 6 P.M., and the minimum about midnight.

A careful quantitative and qualitative investigation of the root relations of the lava inhabiting species is yet to be made, but it already gives promise of yielding some valuable contributions to our knowledge of plant ecology. To quote again from MACDougal (loc. cit., p. 82):

It may be said, in conclusion, that the facts disclosed as to the actual temperatures in the soil, the diurnal and seasonal change therein, lead to the belief that the differences in temperature of the aerial and underground portions of plants cannot fail to be of very great importance in the physical and chemical processes upon which growth, cell-division, nutrition, and propagation depend. The determination of the effect of differences in temperature between the roots and aerial shoots has received but little consideration from the physiologist and the geographer.

\section{Plant invasion on lava flows}

The rate and amount of invasion is chiefly dependent upon two factors: (I) proximity of adjacent vegetated regions from which invasion may take place; (2) amount of precipitation, determining the character and abundance of invading forms. A lava flow which cuts a path through the humid jungle forest is soon ( $30-5^{\circ}$ years) disintegrated and overgrown. A lava flow on an arid summit slope $(8000-10,000 \mathrm{ft}$.) will remain practically naked for centuries. Between these two extreme types every intermediate stage can be found (figs. II, I9, 20).

${ }^{12}$ Cannon, W. A., Root habits of desert plants, p. 20. 


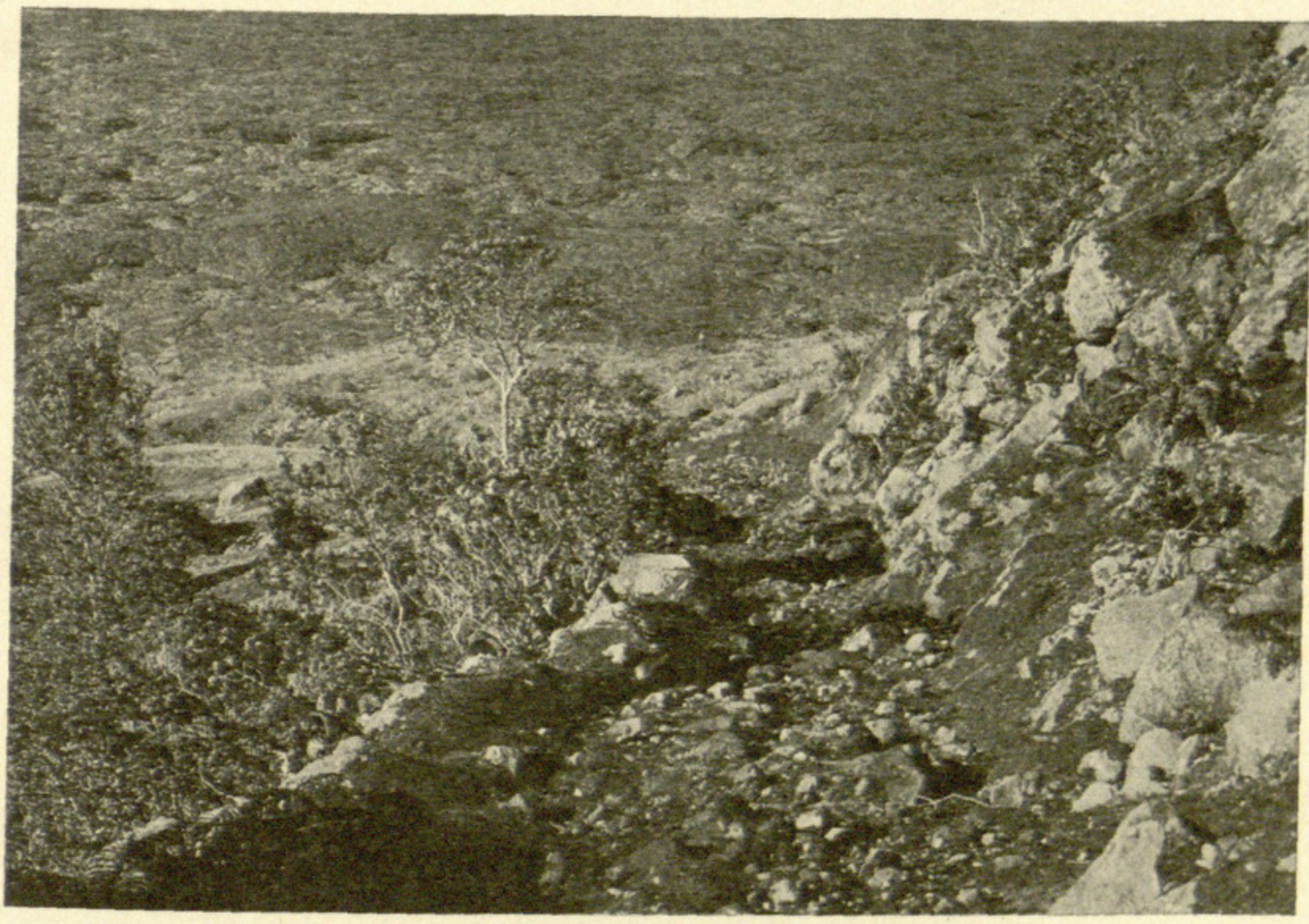

FIG, I9.-Floor of Kilauea, composed of black, lobular, hummocky pa-hoe-hoe; plants in foreground are Metrosideros polymorpha, Vaccinium reticulatum, Sadleria cyatheoides, etc.

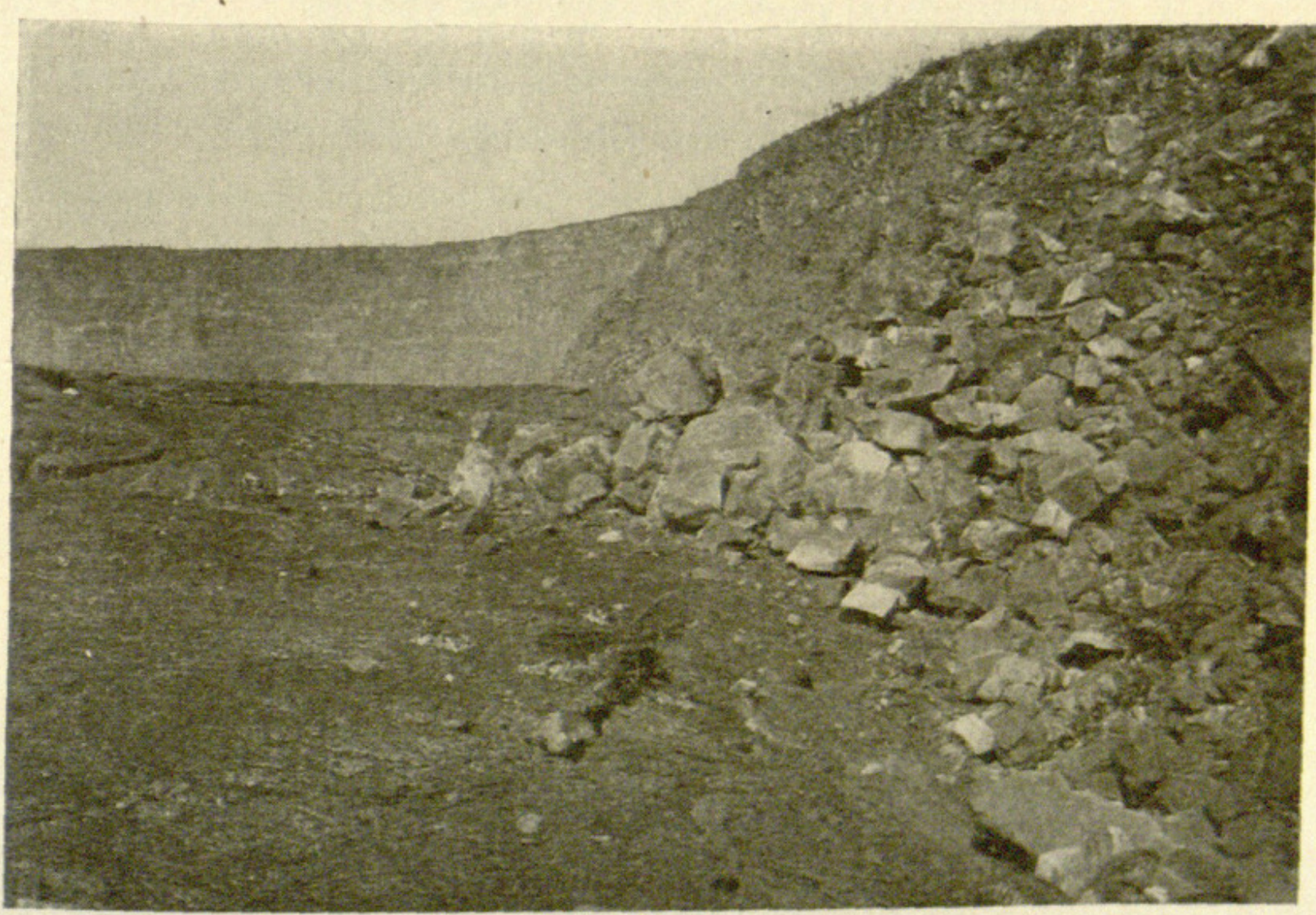

FIG. 20.-Plant invasion on floor of Kilauea crater; near foot of wall; note that floor is smooth pa-hoe-hoe; ferns are Sadleria cyatheoides; scrubby trees near top of slope are Metrosideros polymorpha. 
In IgI2 FORBES ${ }^{13}$ published some preliminary observations of plant invasion on lava flows. His principal findings, which coincide with the observations of the writer, may be summarized as follows:

I. Lichen flora is much more abundant on the $a-a$ than on the pa-hoe-hoe and develops on the former at a much earlier date than the latter, other conditions being the same.

2. Ferns (such as Polypodium and Sadleria) and phanerogams (such as Metrosideros and Sophora) do not establish themselves upon the $a$ - $a$ until long after they have established themselves upon the pa-hoe-hoe, other conditions being the same.

3. The species occupying a recent flow are the same as those occupying older flows in the immediate vicinity.

4. Soil is formed on the pa-hoe-hoe at a much earlier date than on the $a-a$.

5. Acacia koa, a phyllodious species adapted to semi-xerophytic conditions, is the prevailing tree in the leeward upper forests of the middle zone, finally establishing itself upon the ancient flows as the dominant and final type.

\section{Altitudinal ranges of lava flow species}

Horizontal zonation with reference to altitude is strongly developed on the slopes of the Hawaiian mountains. As one ascends a great volcano like Loa or Kea, one finds pronounced changes in the vegetation with every thousand feet increase in elevation. From the standpoint of this paper the following large zones or belts may be recognized: lowland (littoral to I500 ft.), lower forest (1000-2000 ft.), middle forest ( $1800-6000 \mathrm{ft}$.), upper forest (6000-9000 ft.), summit (9000-nearly I4,000 ft.). The summits of Kauai, Oahu, Molokai, West Maui, and Kohala rise to $4000-6000 \mathrm{ft}$. only and are very boggy. They are considered in another paper. ${ }^{14}$ The point must be emphasized that there is a very considerable variation in the altitudinal limitations of these zones on the mountains of the different islands and on different slopes of the same mountain. In some regions the upper forest

${ }^{13}$ Forbes, C. N., Plant invasion on lava flows. Occ. Pap. Bishop Mus. Igí2.

${ }^{4}$ MacCaughey, Vaughan, Vegetation of the Hawaiian summit bogs. Amer. Bot. 22: 45-52. I916. 
may cease at $6_{500} \mathrm{ft}$., in others the lower forest may extend almost to sea level; the figures must all be interpreted with considerable latitude for local deviation.

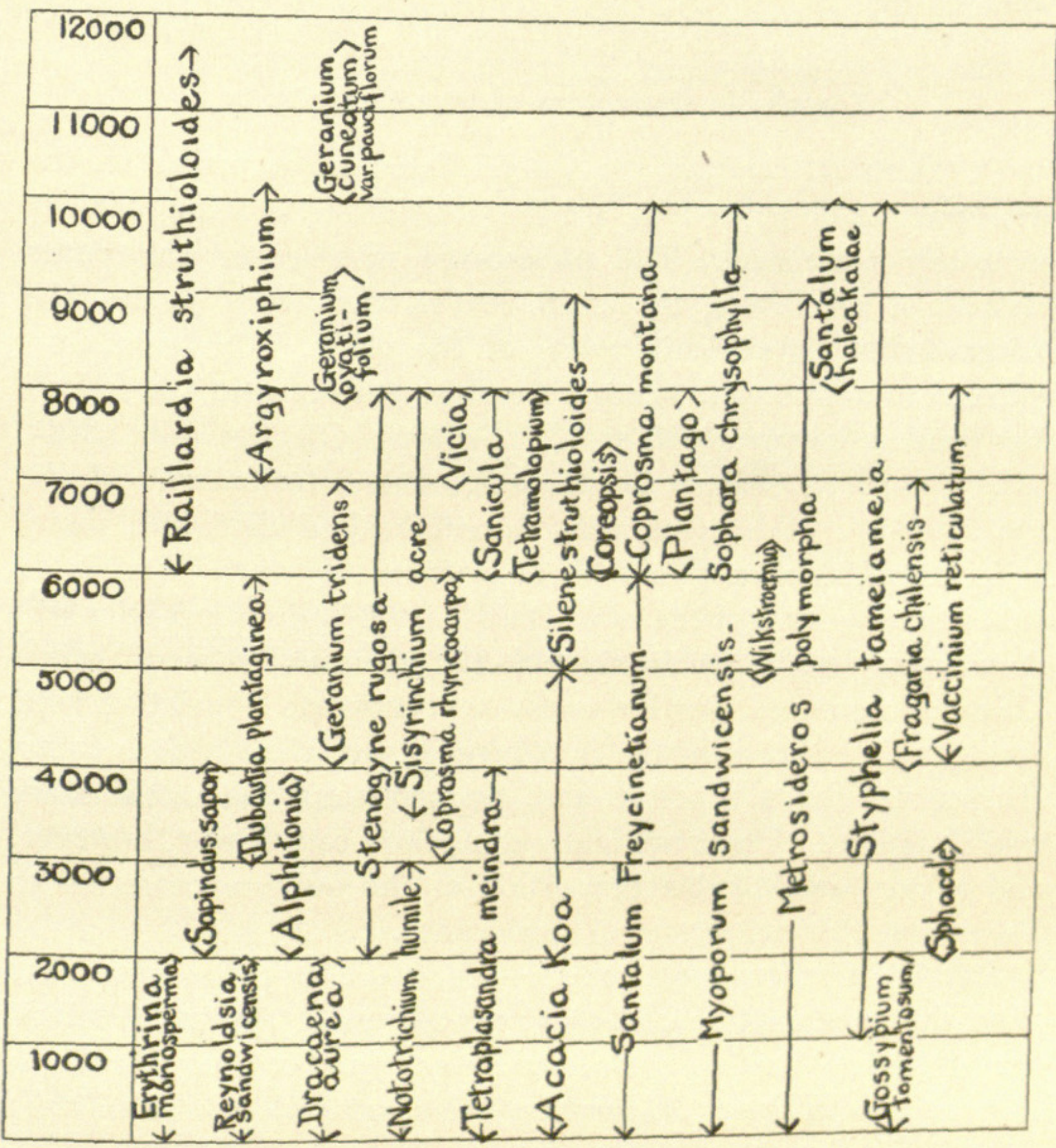

FIG. 21.-Diagram showing altitudinal ranges of some representative plants of lava flow country; figures indicate feet above sea level.

Upon classifying the lava flow species with reference to their altitudinal ranges (fig. 2I), it is significant to note the great number of ranges and the fairly close adherence of each species to its range. Three general types of range may be cited: (I) wide-ranging species (Metrosideros polymorpha, Sophora chrysophylla, Myoporum 
sandwicensis); (2) species with moderate range. (Charpentiera obovata, Daucus pusillus, Gossypium tomentosum); and (3) species with a very narrow range (Argyroxiphium virescens., Geranium spp., Straussia spp.).

\section{Xerophytic characters of lava flow plants}

Pubescence.-Of the 182 species listed as occurring on the lava flows, 62 , or 33 per cent, are characterized by coatings of hairy or woolly tomentum. The pubescence may cover the under surfaces of the leaves, the entire leaves, the young shoots, the inflorescences, or all aerial parts of the plant. The most pronounced examples of tomentose envelopment occur in the following genera: Argyroxiphium, Gnaphalium, Chenopodium, Sida, Gossypium, Nototrichium, Waltheria, Abutilon, Geranium, Lobelia, and Plantago. The point must be emphasized that with many indigenous Hawaiian plants there is exceeding variability as to pubescence; plants of the same species from various localities will show every gradation from perfectly glabrous to very hairy. This variation does not give evidence of intimate association with ecological habitat, although in a general way the glabrous forms characterize the rain forest and the pubescent forms the more arid situations. There are many exceptions to this rule, however, and a very considerable proportion of the pubescence seems to be without obvious ecological significance.

WAXY OR VISCID EXCRETIONS.-These are much less prevalent than the pubescent or coriaceous protections. Typical instances are Argemone mexicana, Dodonea eriocarpa, Gardenia Brighami, Pisonia sandwicensis, $P$. inermis, Plumbago zeylanica, Raillardia spp., Sphacele hastata, Styphelia spp., Tetramolopium spp., Vaccinium spp., Myoporum sp.

THORNS AND PRICKLES.-A small number of the lava flow plants are thorny or prickly; the condition characterizes introduced weeds rather than the indigenous vegetation, as shown by the following:

Prickly Thorny Total

Indigenous.......... I

Introduced .........4 $\quad 5 \quad 9$ 
Acacia Farnensiana, Amaranthus spinosus, Argemone mexicana, Caesalpinia Bonducella, Cyanea solanacea var. quercifolia, Rubus hawaiiensis, Sida spinosa, Solanum incompletum, Opuntia tuna, Lantana camara, and Prosopis juliflora are representative plants of this class (fig. 22).

FOLIAGE MINUTE OR SCALELIKE, or showing strong xerophilous modification.-Acacia koa and A. koaia (phyllodia), Exocarpus Gaudichaudii, Portulaca sclerocarpa, Silene struthioloides, and Styphelia spp. are examples of very small foliage. Cassytha filiformis and Viscum articulatum, two parasitic plants, have minute or vestigial leaves.

Deciduous HABIT.- The deciduous habit is quite rare among Hawaiian plants, either in the rain forest or on the lava fields. Only 3 deciduous species occur on the lava flows, namely, Erythrina monosperma, Sapindus saponaria, and Reynoldsia sandwicensis.

DECUMBENT, STRAGGLING, OR VINELIKE HABIT.-A very large number, nearly 60 in all, or 33 per cent, of the lava flow plants are either habitually prostrate or decumbent, or assume these growthforms on the lava. Genera containing representative species of these habits are Abutilon, Argyreia, Boerhaavia, Caesalpina, Capparis, Cassia, Chenopodium, Cocculus, Embelia, Euphorbia, Fragaria, Gossypium, Ipomoea, Lepidium, Lipochaeta, Meibomia, Mucuna, Osteomeles, Plumbago, Portulaca, Raillardia, Ranunculus, Rubus, Rumex, Scaevola, Sicyos, Sida, Solanum, Stenogyne, Styphelia, Tetramolopium, Vicia, Vigna, and Wikstroemia. Compact basal heads or rosettes are formed by such plants as Argyroxiphium spp., Gnaphalium spp., Plantago pachyphylla, Sisyrinchium acre, Sonchus, etc.

Succulence.-This typical xerophytic character is relatively uncommon in the lava flow flora. The few examples are mostly introduced weeds, as Portulaca, Opuntia, Bryophyllum, Chenopodium, Sonchus. Lignescence, representing the other extreme of structural adaptation to aridity, is the dominant condition.

HIGH PERCENTAGE OF LIGNEOUS FORMS.-Upon examining a tabular statement of the habital characters of the lava flow flora, one is immediately impressed by the high proportion of ligneous and semi-ligneous forms. Over 70 per cent are woody, and this 
proportion would be heightened if a number of herbaceous perennials with woody bases or stocks were included. This ligneous character is not confined to the lava flow plants, however, nor is

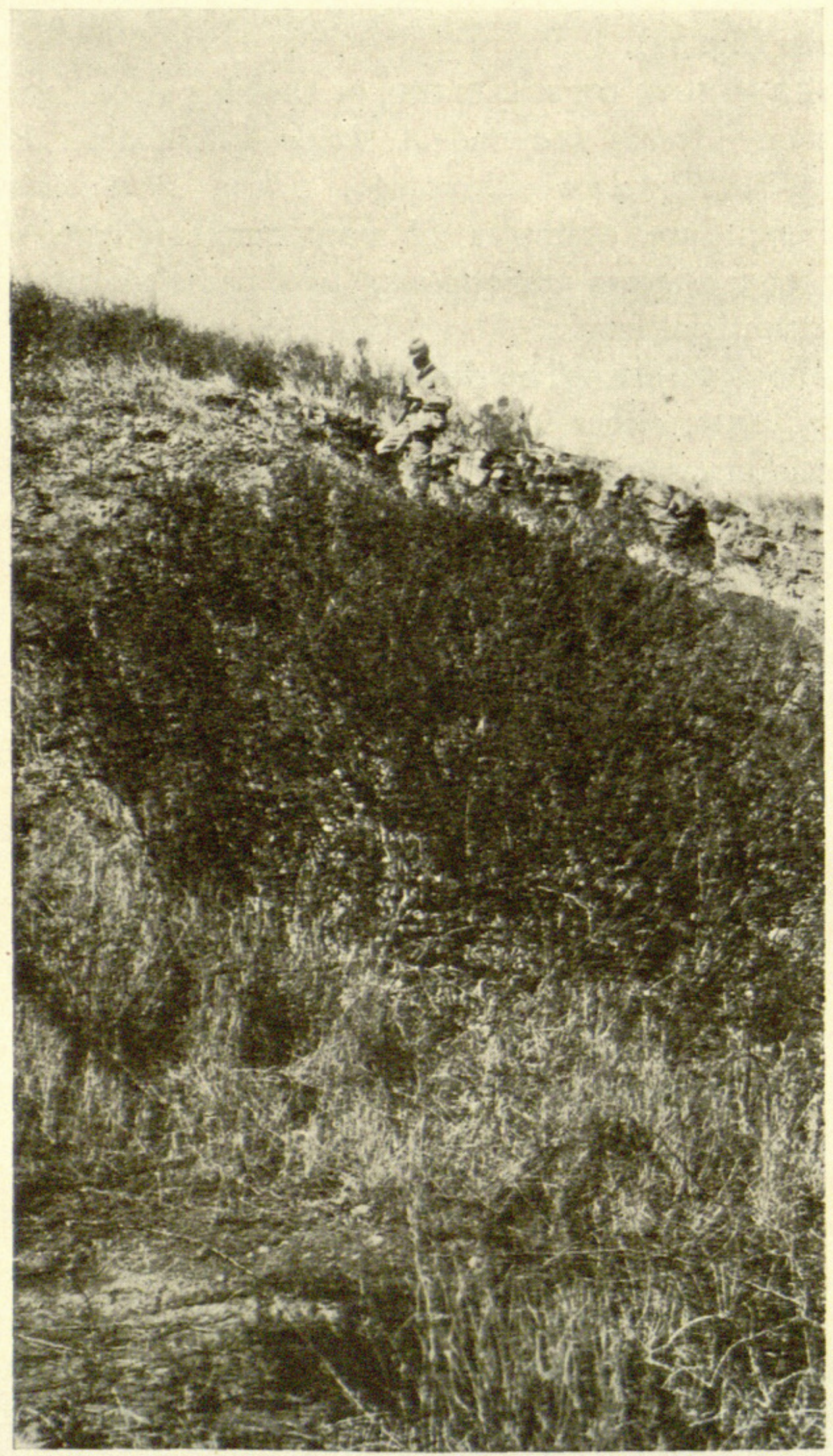

FIG. 22.-Typical ligneous thorny species dominant in xerophytic habitats, on lava flows and coastal plains, Acacia Farnensiana; man is standing on explosively produced tufa strata. 
it especially typical of them. A very large proportion of the indigenous vegetation in the humid forests is shrubby or arborescent.

In the Hawaiian Islands woodiness is to be interpreted, not as a xerophytic feature, but rather as a result of long continued plant growth (in terms of the individual plant) under unfavorable conditions. The low temperatures and excessive humidity of the rain forest belt are probably just as unfavorable for optimum plant growth as are the high temperatures and excessive aridity of the lava fields. Both habitats result in the production or modification of a large number of very lignescent, suffruticose, dwarfed, slow growing species (tables I and II).

\section{TABLE I}

Habital ANALYSIS OF THE LAVA FLOW FLORA

\begin{tabular}{|c|c|c|c|}
\hline Class & Frequent & Rare & Total \\
\hline $\begin{array}{l}\text { Trees.... . . . . . . . . } \\
\text { Shrubs. . . . . . . . . . . . . . . . } \\
\text { Herbaceous perennials } \\
\text { Annuals. . . }\end{array}$ & $\begin{array}{l}48 \\
65 \\
29 \\
24\end{array}$ & $\begin{array}{r}\text { I0 } \\
2 \\
4 \\
2\end{array}$ & $\begin{array}{l}58 \\
67 \\
33 \\
26\end{array}$ \\
\hline
\end{tabular}

TABLE II

ENDEMICITY AND LIGNESCENCE OF LAVA FLOW PLANTS*

\begin{tabular}{c|c|c|c}
\hline Class & Endemic & Not endemic & Total \\
\hline Woody throughout... & 90 & 18 & 108 \\
Partly woody........ & 28 & 10 & 38 \\
Herbaceous........ & 12 & 24 & 36 \\
\hline Total............ & 130 & 52 & 182 \\
\hline
\end{tabular}

* 5 o per cent of the total lava flow flora is composed of woody endemics; 80 per cent of the total lava flow flora is composed of woody and partly woody plants.

RoOT SYSTEMS OF LAVA FLOW PLANTS.-No comprehensive data are available on this interesting subject. The observations of the writer would tend to point to the comparatively deep rootedness of the woody species. The aridity of the flows has already been described. Deeply penetrating roots may be considered as absolutely essential for the existence of perennial plants on a rocky stratum as dry as the typical lava flow. The roots of such species 
as the writer has had occasion to examine have in every case proved to be exceptionally long as compared with the proportions of the aerial parts. The roots run down for long distances into the fissures in the flows, and often pursue the most devious courses. The following plants exhibit this condition: Acacia koa, A. Farnensiana, Alphitonia excelsa, Artemisia australis, Cassia Gaudichaudii, Cheirodendron Gaudichaudii, Coprosma montana, Dodonaea eriocarpa, Erythrina monosperma, Geranium cuneatum, Gossypium tomentosum, Lipochaeta subcordata, Metrosideros polymorpha, Myoporum sandwicensis, Osteomeles anthyllidifolia, Perrottetia sandwicensis, Psidium guayava, Reynoldsia sandwicensis, Rumex giganteus, Senecio vulgaris, Sida fallax, Sophora chrysophylla, Styphelia tameiameiae, Waltheria americana, Wikstroemia spp., Xylosma Hillebrandia.

\section{Sclerophyllous formations}

A considerable proportion of the lava vegetation may be classified as sclerophyllous. The leaves of these species are thick coriaceous, usually with glistening, highly reflective upper surfaces. Antidesma, Chrysophyllum, Coprosma, Maba, Metrosdieros, Nothocestrum, Osmanthus, Pelea, Pisonia, Pittosporum, Pterotropia, Sideroxylon, Styphelia, Wikstroemia, and Xylosma are genera containing typical coriaceous-leaved species. It should be noted that Hawaii does n t exhibit the extreme sclerophyllous condition, but rather a semi-sclerophylly. For example, many species with sclerophyllous foliage do not show noticeable dwarfing; indeed, they may be trees of considerable stature. In the Hawaiian Islands the sclerophyllous formations occur at the higher levels (5000-9000 ft.), and altitude seems to be a dominant factor in their origin and zonation.

AgE OF LAVA FLOW VEGETATION.-The vegetation of the lava flows is largely comprised of woody, long lived species. These acquire the aspect and habit of senility at a relatively early stage in their life cycles. The unfavorable conditions of the environment stamp themselves upon the physiognomy of the individual plants and of the formations as a whole. The woody species give every evidence of great age and slow growth. Shrubs $4^{-6} \mathrm{ft}$. 
high show ages of 30 to 40 years; trees $15^{-20} \mathrm{ft}$. high, ages of 50 to 70 years; and trees of $40-60 \mathrm{ft}$. high, ages of 100 to 200 years or older. It may be stated as a general conclusion that the ligneous plants of the lava flows, like those of other deserts, attain great age and assume the aspect of senility at an early period in their lives.

\section{Fossil trees}

When a lava flow rolls down the mountain slope it may, and commonly does, meet with a grove or woodland across its path. The varying results of the encounter may be summarized as follows:

I. The forest may be entirely consumed by the lava flow, the trees beaten down and burned, and all trace of the grove wiped out by the rock sheet. This usually happens if the flow is $a-a$ and is quite thick. There is abundant evidence on the slopes of Loa, Kea, and Haleakala to show that hundreds of thousands of acres of beautiful woodland have been obliterated by lava flows within comparatively recent geological time.

2. The flow, if of the pa-hoe-hoe type and moving quite rapidly through the grove, may only destroy the foliage, brushwood, and lesser vegetation. The large tree trunks are resistant even to the great heat of the flow. Moreover, the surface lava cools with such extreme rapidity (this is a noteworthy feature of the Hawaiian lavas) that the radiation from within is relatively slight. In this way large trunks are coated with an envelope or shell of lava which quickly cools and hardens, and forms a protective case, so that the heat from adjacent liquid lava does not reach the tree. The main mass of the lava flows on down the slope, leaving the grove spattered and jacketed with lava. Often great blobs of lava remain clinging to the larger limbs and festooning the summits of the saplings. Remnants of woodlands, exhibiting these phenomena, are not uncommon on the lee slopes of Loa.

3. The lava flow, acting under conditions like those just described, but moving more slowly, may ensheath the trees to a considerable height, for example, $20 \mathrm{ft}$. A jacket is formed as has been described, but the gradual incineration of the outer layer of wood results in a space between the tree trunk and the lava jacket. Fresh lava, under pressure, will force its way into this space, and 
its heat will still further reduce the tree trunk. This process is continued until the tree is wholly consumed and the lava has filled the mold. The main flow passes on, leaving the lava trees behind. The result is a lava pillar or column, $15^{-25} \mathrm{ft}$. high, 2-5 ft. in diameter, and often expanded or flaring at the summit, where the trunk branched. These so-called "petrified trees" retain many evidences of their arboreal origin, and correspond somewhat in their mode of formation to the petrified trees of the west. In the Puna district, Hawaii, there are hundreds of these lava trees in the wake of ancient pa-hoe-hoe flows.

4. The fourth type of reaction between lava flow and woodland produces deep tubes instead of columns. The flow enters the grove and fills it to a depth of perhaps $20 \mathrm{ft}$. The rapid sheathing around the trunks of the larger trees protects them, as in the former cases, from immediate destruction. The flow in this instance, however, does not pass on and drain itself from the grove, but remains and solidifies. In the course of time the trunks decay and leave deep tubular vertical pits in the lava. The walls of these tubes are often plainly marked with the impressions of the bark of the trees which they once contained. The tubes are Io in. to $5 \mathrm{ft}$. in diameter and $\mathrm{I}_{5}^{-20} \mathrm{ft}$. deep. They are known as "tree molds," and are abundant on some of the old lava flows, particularly in the vicinity of Kilauea.

College of HawaiI

HONOLULU 

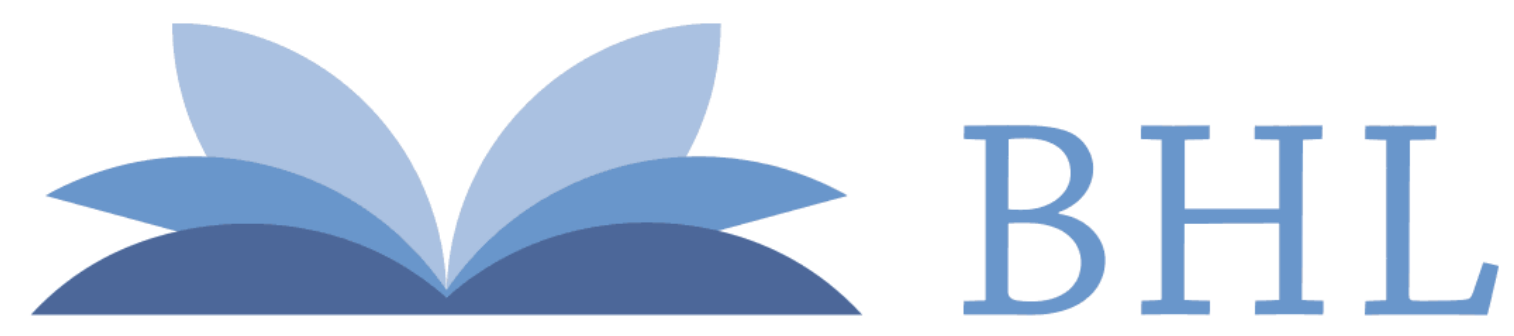

\section{Biodiversity Heritage Library}

Maccaughey, Vaughan. 1917. "Vegetation of Hawaiian Lava Flows." Botanical gazette 64(5), 386-420. https://doi.org/10.1086/332168.

View This Item Online: https://www.biodiversitylibrary.org/item/109348

DOI: https://doi.org/10.1086/332168

Permalink: https://www.biodiversitylibrary.org/partpdf/223946

\section{Holding Institution}

Missouri Botanical Garden, Peter H. Raven Library

\section{Sponsored by}

Missouri Botanical Garden

\section{Copyright \& Reuse}

Copyright Status: Public domain. The BHL considers that this work is no longer under copyright protection.

This document was created from content at the Biodiversity Heritage Library, the world's largest open access digital library for biodiversity literature and archives. Visit BHL at https://www.biodiversitylibrary.org. 